\title{
\#USGS
}

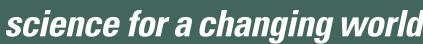

Prepared in cooperation with the Bureau of Reclamation

Simulation of Groundwater Storage Changes in the Eastern Pasco Basin, Washington
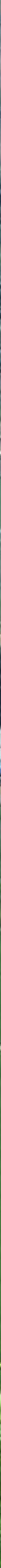

U.S. Department of the lnterior ste fer

U.S. Geological Sunver of 
Cover: Irrigated agricultural fields in Ringold Coulee, 24 miles north of Pasco, Washington.

View to the north includes Pliocene Upper Ringold Formation lacustrine sediments exposed at the head scarp (back cover) and debris from the May 2006 landslide that covered a portion of State Route 170. Photograph by Charles Heywood, U.S. Geological Survey, June 10, 2014. 


\section{Simulation of Groundwater Storage Changes in the Eastern Pasco Basin, Washington}

By Charles E. Heywood, Sue C. Kahle, Theresa D. Olsen, James D. Patterson, and Erick Burns

Prepared in cooperation with the Bureau of Reclamation

Scientific Investigations Report 2016-5026 


\title{
U.S. Department of the Interior SALLY JEWELL, Secretary
}

\section{U.S. Geological Survey Suzette M. Kimball, Director}

\author{
U.S. Geological Survey, Reston, Virginia: 2016
}

For more information on the USGS - the Federal source for science about the Earth, its natural and living resources, natural hazards, and the environment—visit http://www.usgs.gov or call 1-888-ASK-USGS.

For an overview of USGS information products, including maps, imagery, and publications, visit http://www.usgs.gov/pubprod/.

Any use of trade, firm, or product names is for descriptive purposes only and does not imply endorsement by the U.S. Government.

Although this information product, for the most part, is in the public domain, it also may contain copyrighted materials as noted in the text. Permission to reproduce copyrighted items must be secured from the copyright owner.

Suggested citation:

Heywood, C.E., Kahle, S.C., Olsen, T.D., Patterson, J.D., and Burns, Erick, 2016, Simulation of groundwater storage changes in the eastern Pasco Basin, Washington: U.S. Geological Survey Scientific Investigations Report 2016-5026, 44 p., 1 pl., http://dx.doi.org/10.3133/sir20165026.

ISSN 2328-0328 (online) 


\section{Contents}

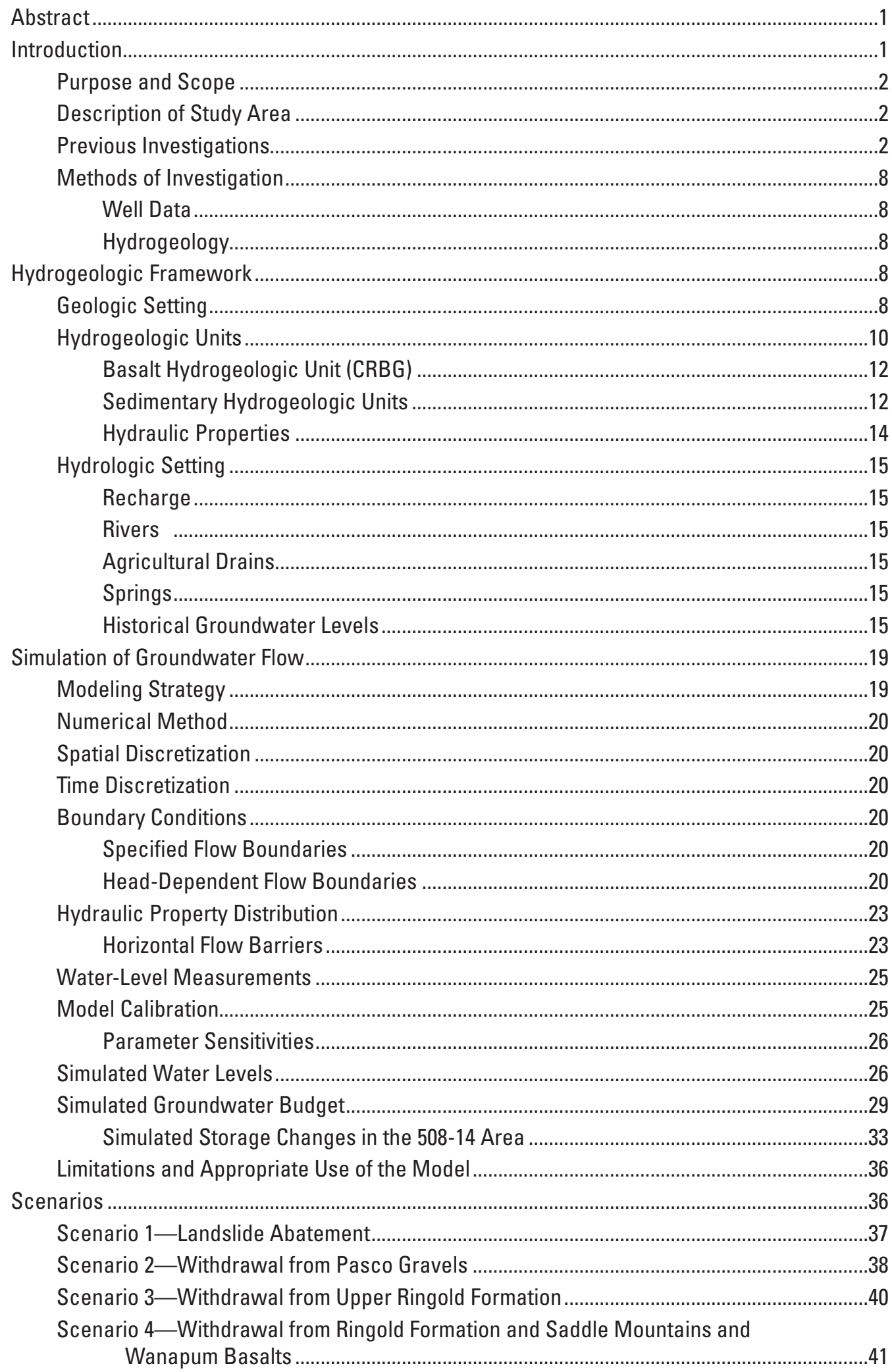




\section{Contents-Continued}

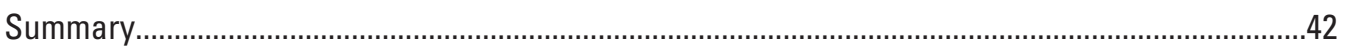

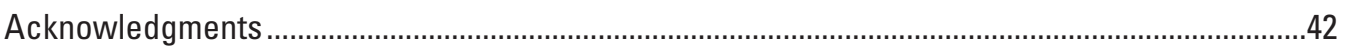

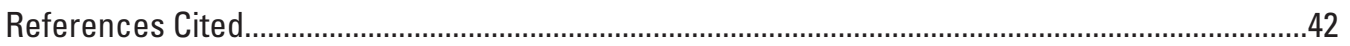

\section{Plate}

1. Hydrologic unit map, hydrogeologic sections, and locations of project wells, eastern Pasco Basin, Washington. download at http://dx.doi.org/10.3133/sir20165026

\section{Figures}

1. Map showing location of the active model domain and 508-14 area, eastern Pasco Basin, Washington.....

2. Map showing simplified National Land Cover of the eastern Pasco Basin, Washington, 2006

3. Map showing locations of rivers, springs, water-delivery infrastructure, buried drains, and pending water-right applications, eastern Pasco Basin, Washington............5

4. Map showing locations of selected hydrogeologic studies of the eastern Pasco Basin and selected adjacent areas, Washington ...........................................................

5. Map showing surficial geology of the eastern Pasco Basin, Washington........................9

6. Map showing top altitude of basalt surface, eastern Pasco Basin, Washington ...........13

7. Map showing extent and thickness of combined overburden units, eastern Pasco Basin, Washington.

8. Map showing water-level altitudes in wells, 1939-45 and hydrograph of well at location B, eastern Pasco Basin, Washington.

9. Map showing finite-difference grid for the groundwater model with river and drain cells, general-head boundary cells, and horizontal-flow barriers, eastern Pasco Basin, Washington

10. Map showing distribution of recharge specified in the Pasco Basin model domain for 2007, eastern Pasco Basin, Washington

11. Map showing SOil WATer balance (SOWAT) model-estimated groundwater withdrawals for 2007 and locations of simulated withdrawal wells, eastern Pasco Basin, Washington

12. Graph showing simulated total annual groundwater withdrawals, eastern Pasco Basin, Washington.

13. Graph showing measured and simulated water levels in the eastern Pasco Basin, Washington.

14. Map showing simulated water-level altitudes, eastern Pasco Basin, Washington, 2013.

15. Map showing simulated changes in water-level altitude, eastern Pasco Basin, Washington, 1920-2013.

16. Graph showing simulated net flows into the groundwater model domain, eastern Pasco Basin, Washington, 1920-2013 


\section{Figures-Continued}

17. Graph showing simulated changes in groundwater storage in the model domain and areas in the 508-14 area, eastern Pasco Basin, Washington,1920-2013

18. Map showing subareas with summarized simulated change in groundwater storage in the active model domain and 508-14 area, eastern Pasco Basin, Washington.

19. Map showing locations of hypothetical wells and simulated drawdown after 7 years of withdrawals at 2 million gallons per day near White Bluffs, eastern Pasco Basin, Washington ...

20. Hydrograph showing simulated water-level altitudes in the upper Ringold Formation near the middle of the hypothetical well field near White Bluffs, eastern Pasco Basin, Washington.

21. Digital imagery showing extent of the Pasco gravels, locations of wells screened in the Pasco gravels and upper Ringold Formation, and the simulated drawdown after 7 years of an additional 1 million gallons per day withdrawal from the upper Ringold Formation, eastern Pasco Basin, Washington

22. Hydrograph showing simulated water-level altitudes where an additional 1 million gallon per day withdrawal was specified from a well screened in the Pasco gravels, eastern Pasco Basin, Washington

23. Hydrograph showing simulated water-level altitudes for the upper and middle Ringold Formations, and the Saddle Mountains and Wanapum Basalts where an additional 1 million gallon per day withdrawal was specified from a well screened in the upper Ringold Formation, eastern Pasco Basin, Washington

24. Hydrograph showing simulated water-level altitudes for the upper and middle Ringold Formations, and Saddle Mountains and Wanapum Basalts where an additional 1 million gallon per day withdrawal was specified from a well screened through the upper and middle Ringold Formation and Saddle Mountains Basalt, eastern Pasco Basin, Washington.

\section{Tables}

1. Comparison of overburden units described in selected hydrogeologic studies in or near the eastern Pasco Basin, Washington

2. Geologic and hydrogeologic units of the eastern Pasco Basin, Washington ..................11

3. Previous estimates of horizontal hydraulic conductivity, storage coefficient, and specific yield in the overburden deposits near the eastern Pasco Basin, Washington.

4. Parameter values and sensitivities for the calibrated groundwater-flow model for eastern Pasco Basin, Washington.

5. Groundwater budget of the 508-14 area, eastern Pasco Basin, Washington, 1900-1920 and 2013

6. Net increase of stored groundwater in subareas of the 508-14 area, eastern Pasco Basin, Washington, 1920-2013.

7. Selected physical and hydrologic data for the project wells in the eastern Pasco Basin study area, Washington. download at http://dx.doi.org/10.3133/sir20165026 


\section{Conversion Factors}

Inch/Pound to International System of Units

\begin{tabular}{|c|c|c|}
\hline Multiply & By & To obtain \\
\hline \multicolumn{3}{|c|}{ Length } \\
\hline inch (in.) & 25.4 & millimeter $(\mathrm{mm})$ \\
\hline foot $(\mathrm{ft})$ & 0.3048 & meter $(\mathrm{m})$ \\
\hline mile (mi) & 1.609 & kilometer $(\mathrm{km})$ \\
\hline \multicolumn{3}{|c|}{ Area } \\
\hline acre & 4,047 & square meter $(\mathrm{m})$ \\
\hline acre & 0.4047 & hectare (ha) \\
\hline square mile $\left(\mathrm{mi}^{2}\right)$ & 2.590 & square kilometer $\left(\mathrm{km}^{2}\right)$ \\
\hline \multicolumn{3}{|c|}{ Volume } \\
\hline acre-foot (acre-ft) & 1,233 & cubic meter $\left(\mathrm{m}^{3}\right)$ \\
\hline acre-foot (acre-ft) & 0.001233 & cubic hectometer $\left(\mathrm{hm}^{3}\right)$ \\
\hline \multicolumn{3}{|c|}{ Flow rate } \\
\hline acre-foot per year (acre-ft/yr) & 1,233 & cubic meter per year $\left(\mathrm{m}^{3} / \mathrm{yr}\right)$ \\
\hline acre-foot per year (acre-ft/yr) & 0.001233 & cubic hectometer per year $\left(\mathrm{hm}^{3} / \mathrm{yr}\right)$ \\
\hline foot per year (ft/yr) & 0.3048 & meter per year (m/yr) \\
\hline cubic foot per day $\left(\mathrm{ft}^{3} / \mathrm{d}\right)$ & 0.02832 & cubic meter per day $\left(\mathrm{m}^{3} / \mathrm{d}\right)$ \\
\hline gallon per day (gal/d) & 0.003785 & cubic meter per day $\left(\mathrm{m}^{3} / \mathrm{d}\right)$ \\
\hline million gallons per day (Mgal/d) & 0.04381 & cubic meter per second $\left(\mathrm{m}^{3} / \mathrm{s}\right)$ \\
\hline inch per year (in/yr) & 25.4 & millimeter per year (mm/yr) \\
\hline \multicolumn{3}{|c|}{ International System of Units to Inch/Pound } \\
\hline Multiply & By & To obtain \\
\hline \multicolumn{3}{|c|}{ Length } \\
\hline meter $(\mathrm{m})$ & 3.281 & foot (ft) \\
\hline kilometer (km) & 0.6214 & mile (mi) \\
\hline
\end{tabular}

Temperature in degrees Fahrenheit $\left({ }^{\circ} \mathrm{F}\right)$ may be converted to degrees Celsius $\left({ }^{\circ} \mathrm{C}\right)$ as ${ }^{\circ} \mathrm{C}=\left({ }^{\circ} \mathrm{F}-32\right) / 1.8$. 


\section{Datums}

Vertical coordinate information is referenced to the North American Vertical Datum of 1988 (NAVD 88).

Horizontal coordinate information is referenced to the North American Datum of 1983 (NAD 83).

Altitude, as used in this report, refers to distance above the vertical datum.

\section{Abbreviations}

$\begin{array}{ll}\text { CBP } & \text { Columbia Basin Project } \\ \text { CRBG } & \text { Columbia River Basalt Group } \\ \text { DEM } & \text { Digital Elevation Model } \\ \text { Ecology } & \text { Washington Department of Ecology } \\ \text { HFB } & \text { Horizontal Flow Barrier } \\ \text { MNW2 } & \text { Multi-Node Well package of MODFLOW } \\ \text { MODFLOW } & \text { USGS modular three-dimensional finite-difference groundwater-flow model } \\ \text { NWIS } & \text { National Water Information System } \\ \text { Reclamation } & \text { Bureau of Reclamation } \\ \text { RMSE } & \text { root-mean-square error } \\ \text { SOWAT model } & \text { SOil WATer balance model } \\ \text { USGS } & \text { U.S. Geological Survey }\end{array}$




\section{Well-Numbering System}

In Washington, wells are assigned numbers that identify their location in a township, range, section, and 40-acre tract. For example, well number 09N/30E-08B02D1 indicates that the well is in township 9 north of the Willamette Base Line, and range 30 east of the Willamette Meridian. The numbers immediately following the hyphen indicate the section (8) in the township, and the letter following the section (B) gives the 40 -acre tract of the section. The two-digit sequence number (02) following the letter indicates that the well was the second one inventoried in that 40 -acre tract. The " $D$ " following the sequence number indicates that the well has been deepened. In the illustrations of this report, wells are identified individually using only the section and 40-acre tract, such as 08B02D1. The townships and ranges are shown on the map borders.

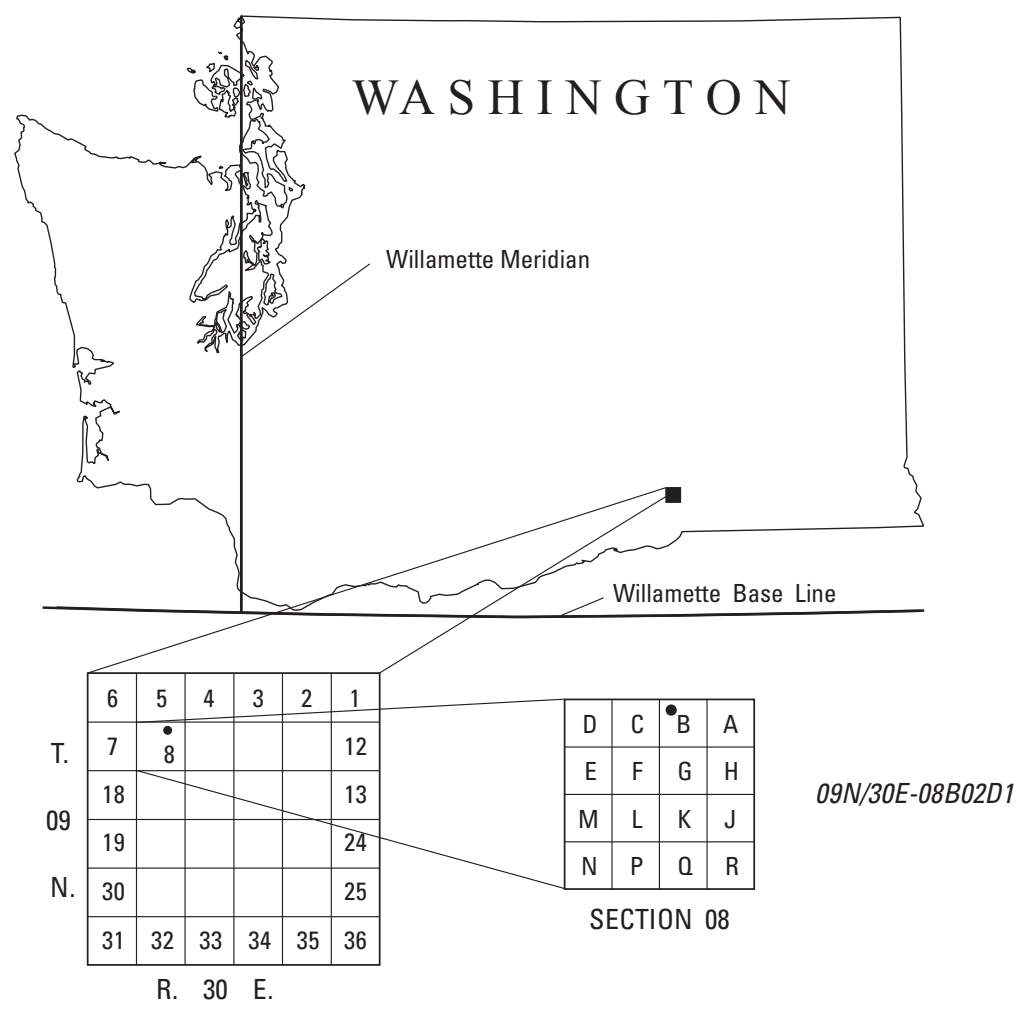

Well numbering system in Washington. 


\title{
Simulation of Groundwater Storage Changes in the Eastern Pasco Basin, Washington
}

\author{
By Charles E. Heywood, Sue C. Kahle, Theresa D. Olsen, James D. Patterson, and Erick Burns
}

\section{Abstract}

The Miocene Columbia River Basalt Group and younger sedimentary deposits of lacustrine, fluvial, eolian, and cataclysmic-flood origins compose the aquifer system of the Pasco Basin in eastern Washington. Irrigation return flow and canal leakage from the Columbia Basin Project have caused groundwater levels to rise substantially in some areas, contributing to landslides along the Columbia River. Water resource managers are considering extraction of additional stored groundwater to supply increasing demand and possibly mitigate problems caused by the increased water levels. To help address these concerns, the transient groundwater model of the Pasco Basin documented in this report was developed to quantify the changes in groundwater flow and storage. The MODFLOW model uses a 1-kilometer finite-difference grid and is constrained by logs and water levels from 846 wells in the study area. Eight model layers represent five sedimentary hydrogeologic units and underlying basalt formations. Head-dependent flux boundaries represent the Columbia and Snake Rivers to the west and south, respectively, underflow to and (or) from adjacent areas to the northeast, and discharge to agricultural drains, springs, and groundwater withdrawal wells. Specified flux boundaries represent recharge from infiltrated precipitation and anthropogenic sources, including irrigation return flow and leakage from water-distribution canals. The model was calibrated with the parameter-estimation code PEST ++ to groundwater levels measured from 1907 through 2013 and measured discharge to springs and estimated discharge to agricultural drains. Increased recharge since pre-development resulted in a 6.8 million acre-feet increase in storage in the 508-14 administrative area of the Pasco Basin. Four groundwatermanagement scenarios simulate the 7-year drawdown resulting from withdrawals in different locations. Withdrawals of 2 million gallons per day (Mgal/d) from a hypothetical well field in the upper Ringold Formation along the Columbia River could generate 30-70 feet of drawdown, which may reduce landslide susceptibility along the White Bluffs. Drawdowns resulting from a $1 \mathrm{Mgal} / \mathrm{d}$ withdrawal from wells screened in either Pasco gravels, upper Ringold Formation, or both Ringold Formation and underlying basalt are simulated in the other three scenarios, and differ because of the contrasting hydraulic conductivities within the screened intervals.

\section{Introduction}

Since 1952 water diverted from the Columbia River has been used to irrigate parts of the Bureau of Reclamation (Reclamation) Columbia Basin Project (CBP) in eastern Washington. As a result of the large volumes of surface-water irrigation, groundwater levels in the Pasco Basin sediments generally have risen and caused various problems, such as landslides along the Columbia River, septic system failures, and loss of agricultural lands because of ponding. As demands for water use increase, State and local water resource managers are increasingly looking to the additional groundwater in storage as a potential source of water for development. The development of these groundwater resources not only could provide additional water for beneficial use, but also could potentially mitigate some of the adverse consequences of the rise in water levels.

There is a need to better understand the groundwaterflow system before and after the start of surface-water irrigation in eastern Washington, and to quantify the increases in groundwater fluxes and storage attributed to excess irrigation. Under Washington State law, subject to existing rights, all natural groundwater and all "artificially stored" groundwater that has been abandoned or forfeited are available for appropriation (Washington Administrative Code [WAC] 508-14-030). The sedimentary deposits underlying the Pasco Basin have large quantities of groundwater in "artificial" storage that could be made available for a Declaration of Claim, but the storage volume attributed to the CBP irrigation is unknown.

State and local water resource managers are considering extraction of the additional stored groundwater to supply increasing demand, as well as possibly mitigating problems caused by rising water levels. To manage future groundwater allocations, an assessment of increased groundwater storage attributed to irrigation return flow from CBP irrigation is needed. 


\section{Purpose and Scope}

The "508-14 area" is the area in the Pasco Basin designated by Chapter 508-14 of the Washington Administrative Code (WAC) in which the Washington State Department of Ecology (Ecology) regulates groundwater withdrawals. In 2002, Washington State legislation (Substitute House Bill 2874) recognized Reclamation ownership of artificially stored groundwater and authorized Ecology to enter into a joint management program with Reclamation to issue permits for groundwater withdrawals from the 508-14 area of Franklin County. Since 2002, Ecology and Reclamation have actively pursued development of a 508-14 groundwater management program to permit withdrawals of commingled naturally occurring and artificially stored 508-14 groundwater. The U.S. Geological Survey (USGS), in cooperation with the Bureau of Reclamation conducted this study to quantify natural and artificially stored groundwater in the 508-14 area. This report documents the groundwater-flow model that was developed to quantify the changes of groundwater storage in eastern Pasco Basin, Washington.

The four primary objectives of this study are to:

1. Define the hydrogeology of the study area,

2. Determine groundwater flow directions and flows through the aquifer system,

3. Quantify the effect of anthropogenic recharge and groundwater withdrawals on storage in the groundwater system, and

4. Simulate the effects of four groundwatermanagement scenarios.

\section{Description of Study Area}

The Pasco Basin study area includes the 508-14 area in Adams, Franklin, and Grant Counties (fig. 1), and encompasses 2,192 $\mathrm{mi}^{2}$ in the Columbia Plateau Province. Altitudes in the area range from $340 \mathrm{ft}$ along the Columbia River near Pasco to $2,700 \mathrm{ft}$ in the Saddle Mountains, with an average altitude of about $900 \mathrm{ft}$. The climate is arid to semi-arid, with mean annual precipitation ranging from 7 to 10 in. and occurring primarily during the winter. Average temperatures range from the upper $20 \mathrm{~s}^{\circ} \mathrm{F}$ in December and January to more than $90^{\circ} \mathrm{F}$ in July and August.

The 2010 population of the study area was about 40,000 , at which time the largest city was Othello, Washington, with a population of 7,400 . The three most common types of land cover in the study area during 2006 (fig. 2) were planted/cultivated crops (51 percent), followed by shrubland (38 percent) and developed (5 percent). Use of groundwater resources in the Pasco Basin began in the late 1800s, when groundwater was withdrawn for agriculture, stock watering, and domestic use. In the 1950s, the CBP began to deliver water diverted from the Columbia River at Grand Coulee Dam for large-scale agricultural development. Subsequently, groundwater levels generally have risen in the shallow basin-fill sediments.

Although groundwater withdrawals have increased since the 1950s, surface-water irrigation systems supply most of the agricultural water demand in the study area. Water obtained from the Columbia River is distributed through a system of canals and pipes, or buried drains (fig. 3), and excess irrigation water that is not recycled through drains and wasteways recharges the groundwater system. As of 2014, there were 140 pending water-right applications in the study area (John J. Covert, Washington State Department of Ecology, written commun., December 2014) (fig. 3).

\section{Previous Investigations}

Regional and site-specific hydrogeologic investigations have reported on the hydrogeologic framework and hydrologic characteristics of the Pasco Basin. Selected studies are discussed here; the locations of these studies are shown in figure 4 , and a comparison chart of the overburden units described is included in table 1.

Some of the earliest hydrogeologic studies in the Pasco Basin were associated with the development of the Hanford Nuclear Reservation (Hanford Site), and later studies characterized radionuclide contamination in and around the Hanford Site. Investigations in the early and mid-1970s by Newcomb and others (1972) and Tanaka and others (1974) (fig. 4) characterized the hydrogeologic properties of the overburden and the underlying basalt, including the transmissivity of each hydrogeologic unit. These investigations used well tests to determine hydraulic characteristics, mapped hydrogeologic-unit thicknesses, and documented water-level changes caused by artificial recharge.

In the mid-1980s through late 1990s, Drost and Whiteman (1986); Drost and others (1989a, 1989b, 1990, 1993, 1997), and Ebbert and others (1996) completed a series of investigations to characterize the surficial geology, structure, top altitudes and thicknesses of hydrogeologic units, water levels and quality, and various components of groundwater recharge and discharge in the area of this study. Some of these investigations encompassed the entire Columbia Plateau (Drost and Whiteman, 1986; Drost and others, 1990), whereas the remainder focused on the Pasco Basin (Drost and others, 1989a, 1989b, 1993, 1997; Ebbert and others, 1996). Drost and others (1997) developed and interpreted contoured potentiometric-surface maps, and summarized the water-level change from pre-development to 1986. The present study area contains about two-thirds of the $900 \mathrm{mi}^{2}$ Drost and others study area (fig. 4), in which Drost and others estimated a groundwater-storage increase of about 5 million acre-ft between 1950 and 1986. 


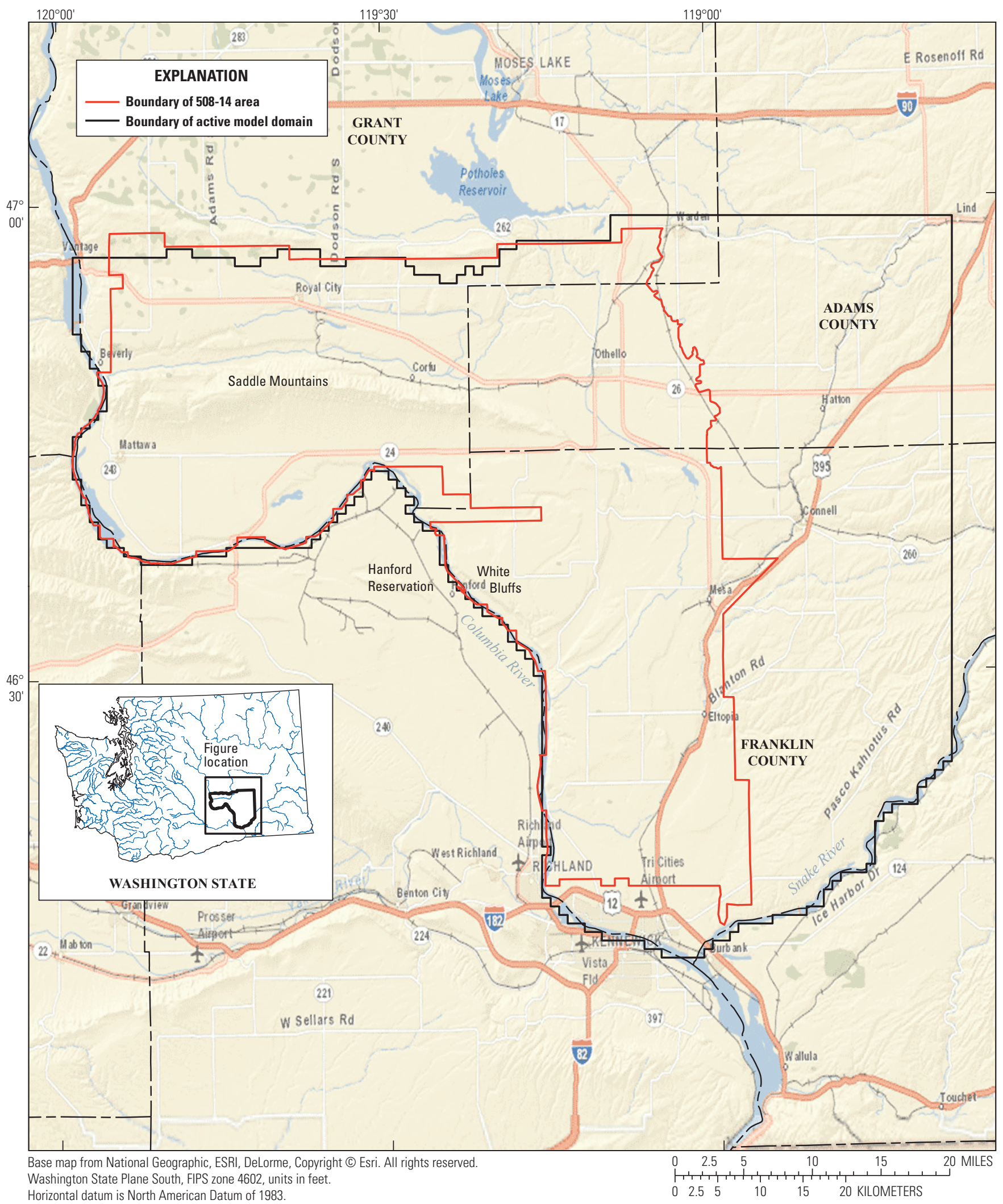

Figure 1. Location of the active model domain and 508-14 area, eastern Pasco Basin, Washington. 


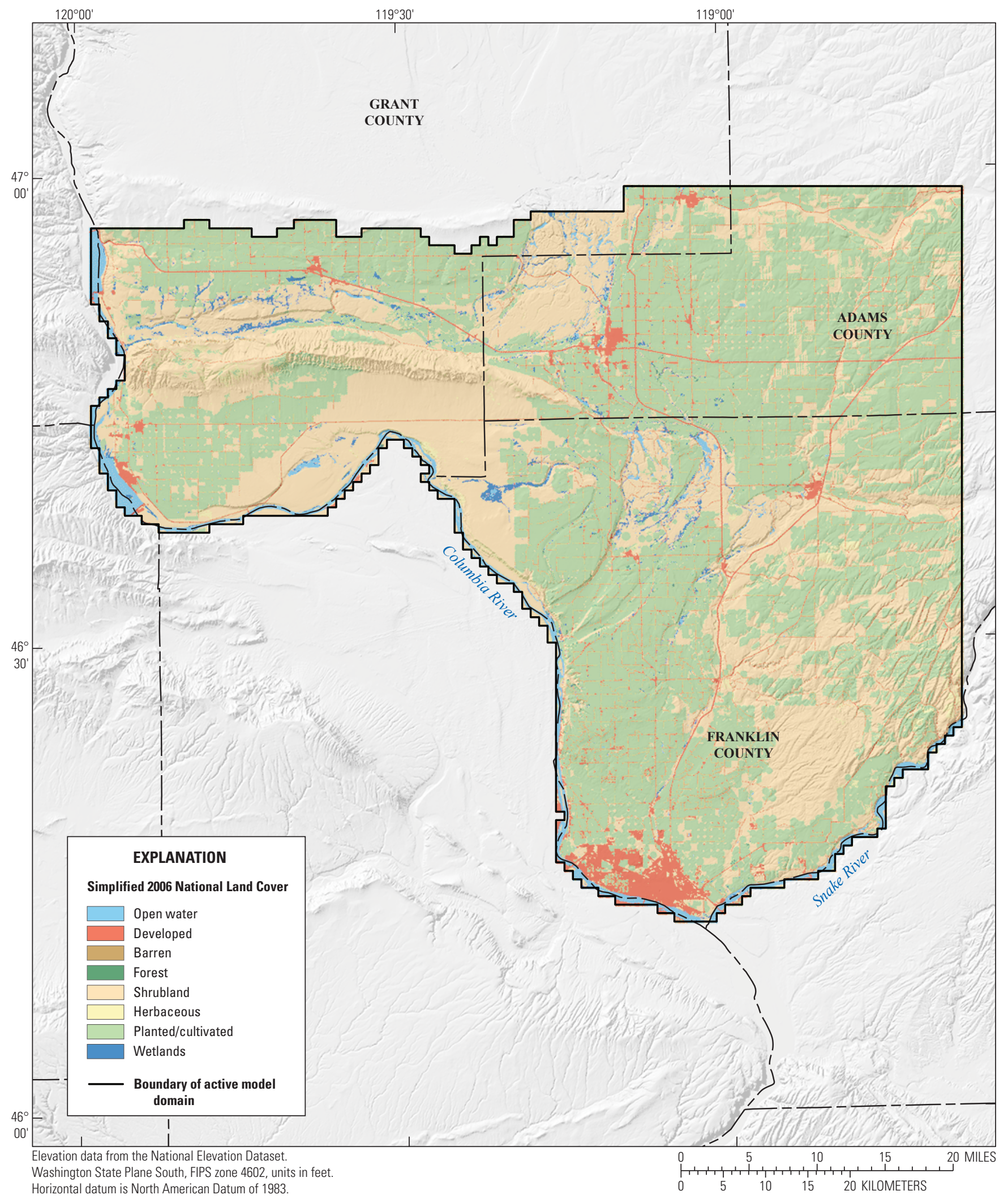

Figure 2. Simplified National Land Cover of the eastern Pasco Basin, Washington, 2006. 


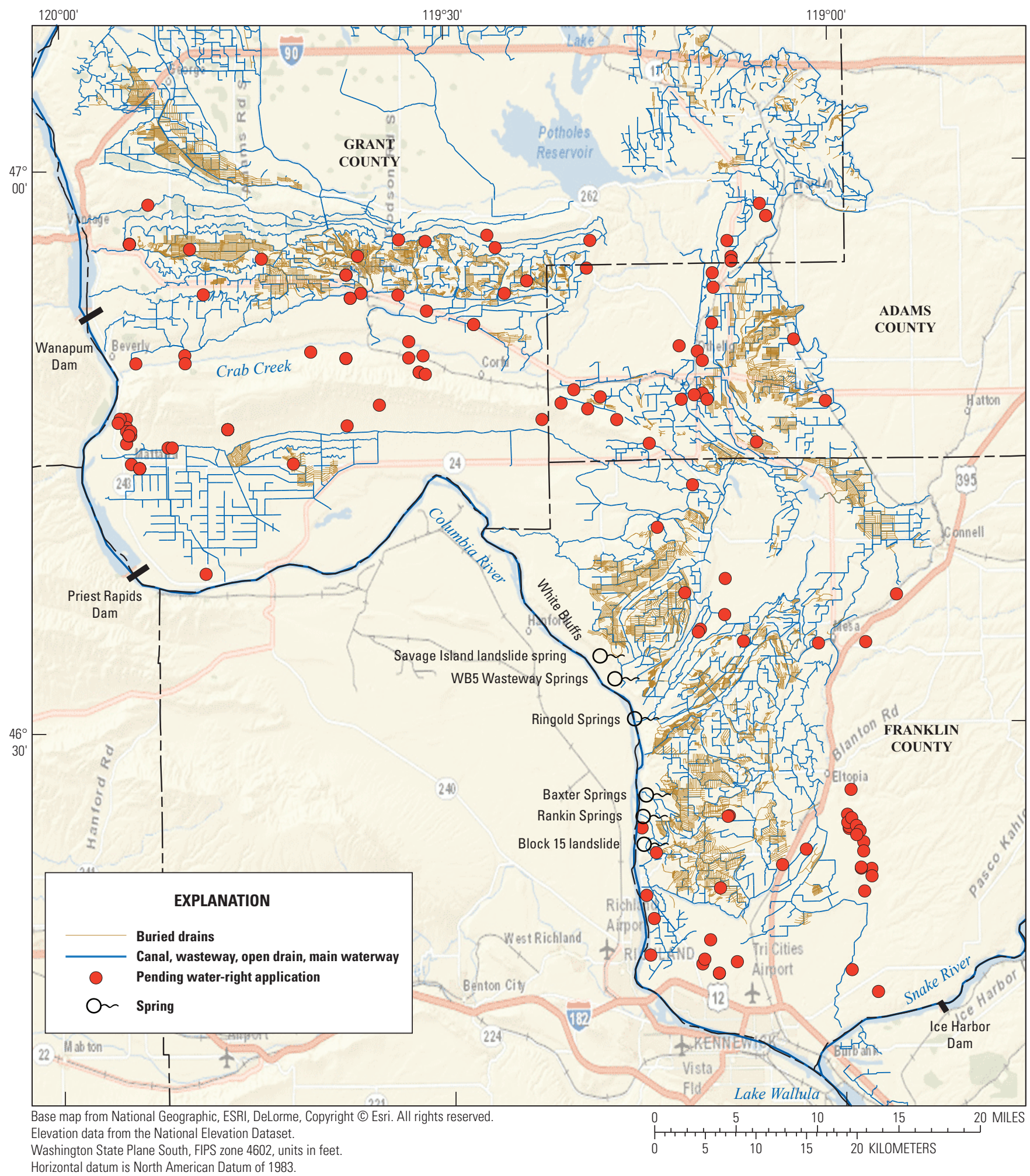

Figure 3. Locations of rivers, springs, water-delivery infrastructure, buried drains, and pending water-right applications, eastern Pasco Basin, Washington. 


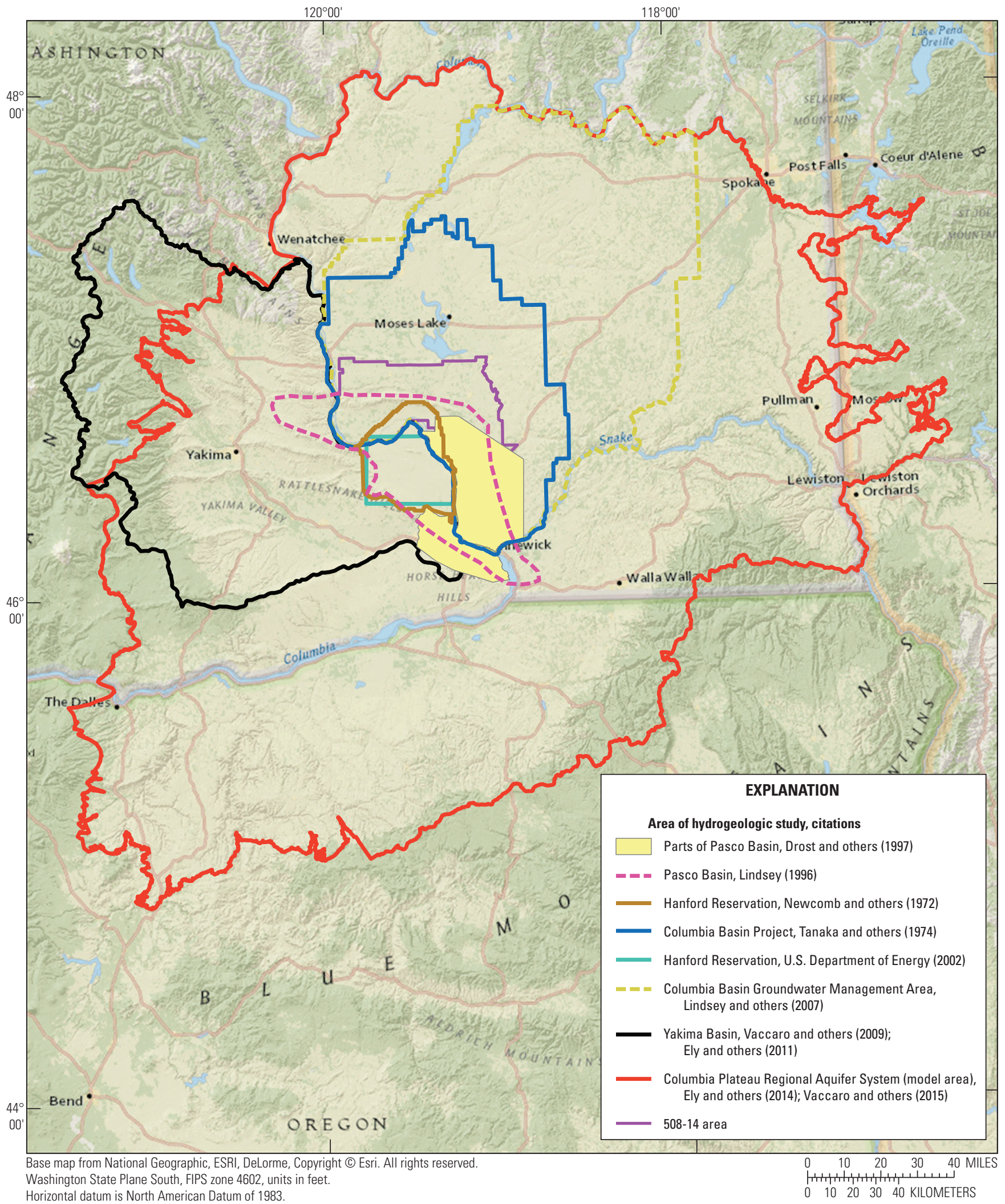

Figure 4. Locations of selected hydrogeologic studies of the eastern Pasco Basin and selected adjacent areas, Washington. 
Introduction

7

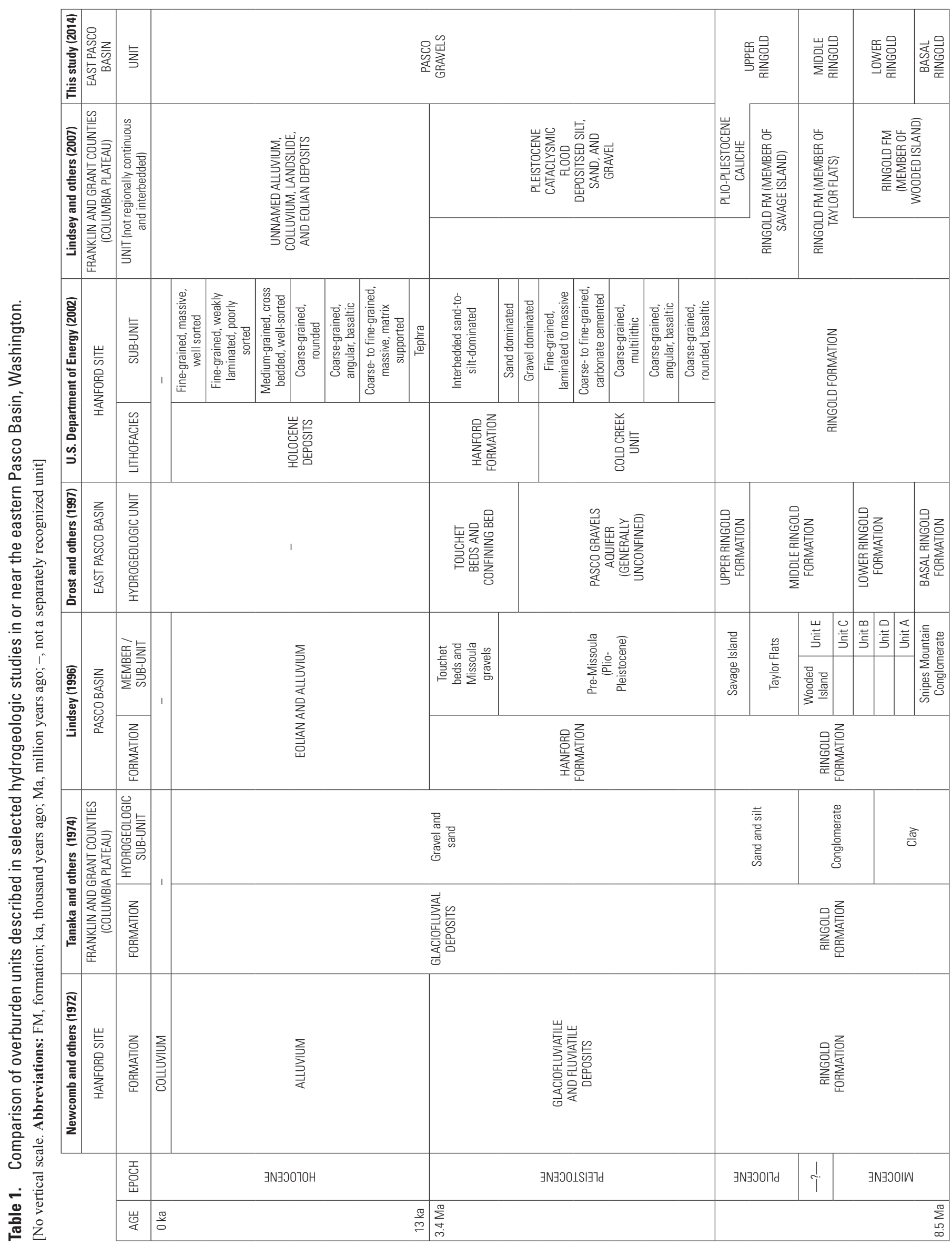


Simulation of Groundwater Storage Changes in the Eastern Pasco Basin, Washington

Bauer and Vaccaro (1990) developed a model to quantify groundwater recharge to the Columbia Plateau Regional Aquifer System during pre-development and 1975 land-use conditions. A rigorous error analysis was not done, and they estimated a maximum uncertainty of 25 percent for their recharge calculations.

Lindsey (1996) described the stratigraphy of the Miocene-Pliocene Ringold Formation and associated deposits of the ancestral Columbia River system in the Pasco Basin (fig. 4). The U.S. Department of Energy (2002) standardized the stratigraphic nomenclature for post-RingoldFormation sediments (table 1) in the Central Pasco Basin and described their lithology and depositional setting. Lindsey and others (2007) described the geologic framework of the sedimentary aquifer system in the Columbia Basin Ground Water Management area of Adams, Franklin, and Grant Counties (fig. 4).

Recent studies of the hydrogeologic framework, water budget, groundwater conditions, and post-development trends in the regional Columbia Plateau Regional Aquifer System encompass the current study area and focus on the basalt aquifers (Snyder and Haynes, 2010; Kahle and others, 2011; Burns and others, 2012; Vaccaro and others, 2015). These studies provided data used for the construction of a threedimensional numerical model of groundwater flow in the Columbia Plateau Regional Aquifer System (Ely and others, 2014), which was used to specify recharge, groundwater withdrawal, and groundwater underflow fluxes in the model documented by this report.

\section{Methods of Investigation}

\section{Well Data}

Construction, geophysical log, and water-level data from 846 wells in the project area were compiled from 811 sites retrieved from the USGS National Water Information System (NWIS) database and 35 wells from the Ecology well-log database. The three criteria for selecting wells from NWIS were: (1) sites located in the study area were previously visited by USGS personnel, (2) complete construction information and well logs were available, and (3) multiple water-level measurements were available.

The 35 additional wells compiled from the Ecology welllog database were used in areas where NWIS well data were not available using the three well-selection criteria. These wells were not field-located and were assigned approximate latitude and longitude coordinates using the public land survey locations (township, range, section, and quarter-quarter section), well addresses, and (or) parcel numbers available on the drillers' logs for each well. The locations of all 846 project wells are shown on plate 1 , and selected physical and hydrologic data for these wells are provided in table 7.
Table 7. Selected physical and hydrologic data for the project wells in the eastern Pasco Basin study area, Washington.

[Table 7 is a Microsoft ${ }^{\circ}$ Excel file and can be downloaded at http://dx.doi. org/10.3133/sir2065026]

\section{Hydrogeology}

A map of the surficial hydrogeology of the study area was made by grouping surficial geologic units of similar lithology and extent into hydrogeologic units, and was further refined with lithologic information obtained from drillers' logs of area water wells (fig. 5 and pl. 1). A digital tabulation of borehole hydrogeologic unit assignments facilitated creation of seven hydrogeologic cross sections and correlation of hydrogeologic units at depth (pl. 1). Raster representations of the top altitudes (surfaces) and extents of the hydrogeologic units described in this report were generated using a grid with square cells $100-\mathrm{ft}$ on a side in a geographic information system. These surfaces were used to construct the digital hydrogeologic framework for the USGS modular three-dimensional finite-difference groundwater-flow (MODFLOW) model. Unit-top altitudes at project wells were interpolated through the extent of the hydrogeologic units using the Australian National University Digital Elevation Model (ANUDEM) procedure (Hutchinson, 1989). Each hydrogeologic unit surface was constrained by the National Elevation Dataset 100-ft land surface Digital Elevation Model (DEM) where the unit outcropped.

The interpolated hydrogeologic unit surfaces and thicknesses were compared to previous hydrogeologic-unit maps, sections, and well interpretations to honor previous data interpretations wherever feasible. Hydrogeologic-framework uncertainties are greatest in areas where the surficial geology changes abruptly, or the project wells do not provide sufficient subsurface lithologic data.

\section{Hydrogeologic Framework}

\section{Geologic Setting}

The study area lies in the eastern half of the Pasco Basin, which is a structural and topographic low area in south-central Washington. Most locally significant groundwater occurs in three major stratigraphic units that underlie the eastern Pasco Basin. In ascending order, these units are (1) the Columbia River Basalt Group (CRBG), (2) the Ringold Formation, and (3) the sediments deposited by catastrophic flooding (Drost and others, 1997). A map of the surficial geology of the study area (fig. 5) was simplified from the digital geologic map database of Washington (Washington Division of Geology and Earth Resources, 2005). 


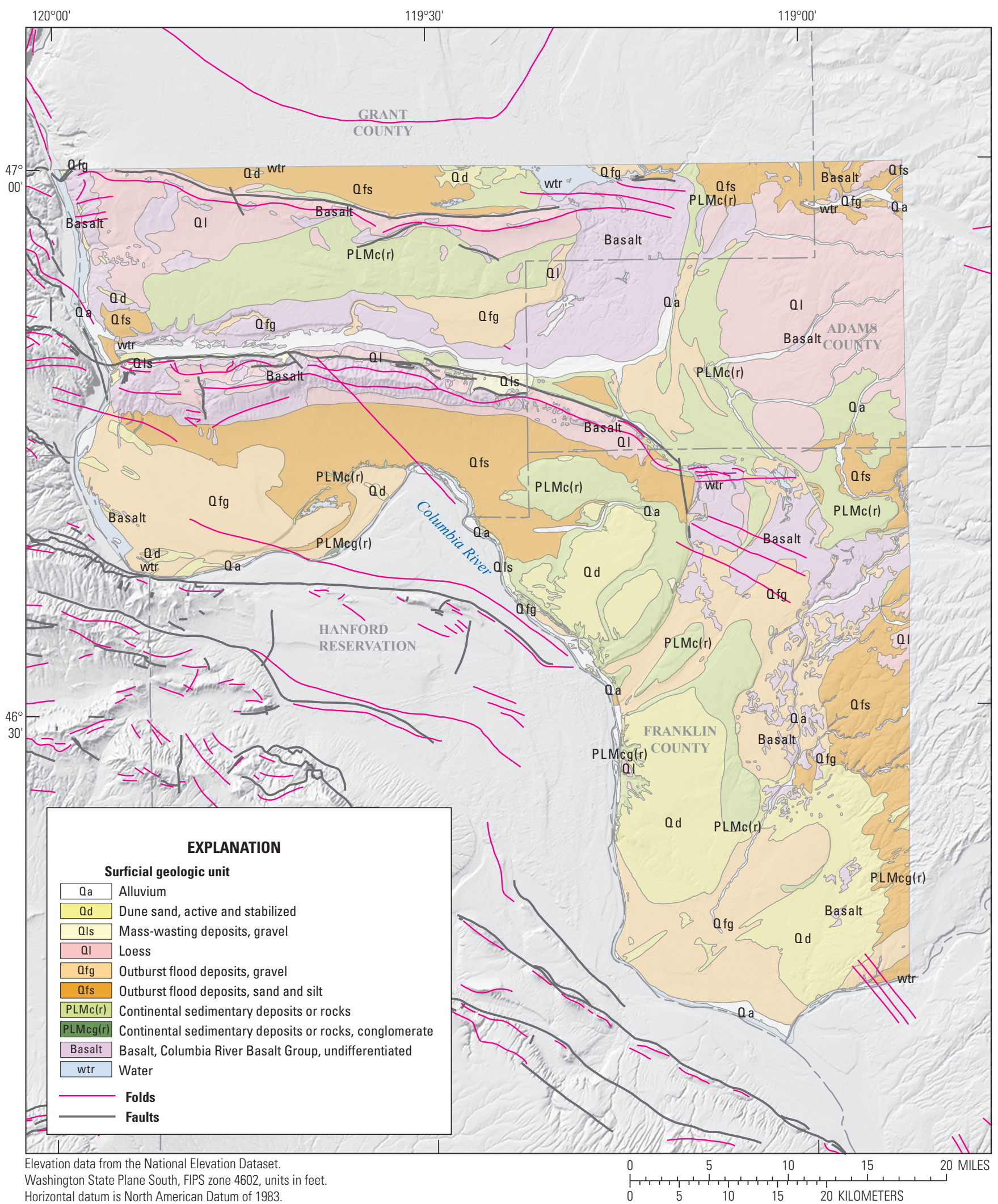

Figure 5. Surficial geology of the eastern Pasco Basin, Washington. 
The geologic and hydrogeologic setting of the area described by Drost and others (1997) is summarized here. During the Tertiary period, basalts intermittently flooded into the Pasco Basin, creating a basalt-layer sequence greater than $15,000 \mathrm{ft}$ thick. Between eruptions, particularly those producing the younger flows, minor amounts of sediment (Ellensburg Formation) were interbedded with the basalts. Northwest- to west-trending folds were formed during late stages of the flood basalt volcanism. At that time, the greatest deformation was west of the study area in the Yakima fold belt that extends eastward into the study area in the Saddle Mountains, within which the Saddle Mountains Fault (Lidke, 2002) is a major structural feature.

Regional folding and subsidence of the basalts in the Late Miocene resulted in the deposition of fluvial sediments in the Pasco Basin by ancestral rivers flowing into and through the basin. These sediments formed the Ringold Formation of Miocene - Pliocene age, which consists of four textural sub-units referred to as the basal, lower, middle, and upper Ringold Formation (table 1).

The basal Ringold Formation, which is a coarse gravel conglomerate, typically is less than $20 \mathrm{~m}$ thick and resulted from the deposition of channel bedload on braided plains. This deposition is limited to the farthest lateral extent of the shallow, shifting channels. There also were occasional silt overbank deposits near the channel from individual flood events. This conglomerate deposition pre-dates the northsouth regional shortening of the basalts that formed the basin topography (Brown and Brown, 1965; Lindsey, 1996).

As structural deformation began to obstruct the river systems, a shallow lake formed in the new basin. The gradual formation of Ringold Lake slowly changed the depositional setting. Silt and clay were deposited above the basal Ringold Formation and the basalt bedrock (outside the former channel boundaries) throughout the basin. Blue clay that was deposited and preserved in an anaerobic environment and sporadic sandy gravels deposited during flood events typically were identified by Drost (1997) as the lower Ringold Formation (Brown and Brown, 1965).

As a new channel began to form and provide an outlet for the basin, Ringold Lake slowly drained. The river once again re-channelized into a shifting braided system. Frequent flood events continued to produce fine-grained silt and clay overbank deposits throughout the basin, similar in texture and composition to those in the lower Ringold Formation. Conglomerate in the middle Ringold Formation formed in river channels and continued to thicken as the basin subsided (6.5-5.5 Ma). Although the quantity of gravel deposited generally decreases with distance from a channel swath, channel migration and repeated floods of various sizes resulted in conglomerate, well-sorted sands, and overbank deposits that routinely inter-finger, pinch out, or form lenses (Brown and Brown, 1965; Lindsey, 1996; Drost and others, 1997).
About $5.5 \mathrm{Ma}$, the basin began to fill again, forming a shallow lake. Sands, silts, and clays filled the basin with 30 to more than $230 \mathrm{~m}$ of fine-grained laminated sediments in the upper Ringold Formation. These fine-grained sediments are similar in composition and hydraulic characteristics to those in the lower Ringold Formation. After Ringold Lake drained, a calcium-carbonate $\left(\mathrm{CaCO}_{3}\right)$ precipitate formed that cemented the fine-grained sedimentary surface with a thick caliche layer. Subsequent to the formation of the caliche layer, severe dust storms left thick eolian deposits in low-lying areas (Lindsey, 1996; Drost and others, 1997).

The Pasco gravels are unconsolidated sandy gravels deposited during the Missoula floods that overly the Ringold Formation. The contact between the Ringold Formation and the Pasco gravels is an irregular disconformity, caused by high-energy erosion during the initial stages of flooding. A temporary lake again filled the basin due to a downstream restriction in the Columbia River Gorge. The Missoula flood deposits consist of very poorly sorted sediments ranging from silts to boulders. The coarsest material was deposited near the river channel. Sedimentation farther from the channel consists of fine-grained slack-water deposits. The size of the lake was directly related to the volume of floodwater. The varying size of flood pulses created inter-fingering between the coarse- and fine-grained deposits (Lindsey, 1996).

Holocene post-Missoula-flood deposits consist of eolian loess, slope wash, eolian dune sand, alluvium, talus, landslide/debris flow, and volcanic ash. Both the fine-grained, well-sorted wind deposits and the poorly sorted, massive landslide and debris-flow deposits typically are unweathered and unconsolidated. These silts, sands, and gravels generally are less than $5 \mathrm{~m}$ thick (U.S. Department of Energy, 2002).

\section{Hydrogeologic Units}

All geologic units described in the section, "Geologic Setting," function either as aquifers or confining units in some parts of the study area. The sediments above the basalt were separated into hydrogeologic units based on their textures and position, following the hydro-stratigraphic classification of Drost and others (1997) (table 2). Fine- and coarse-grained sedimentary units alternate in sequence from the Pasco gravels downward through the basal Ringold Formation. The coarse-grained units (Pasco gravels, middle and basal Ringold Formation) generally form productive aquifers where saturated. The fine-grained units (upper and lower Ringold Formation) have smaller hydraulic conductivity and generally function as confining units that produce small quantities of water to wells that may be completed in them. Due to their storativity, however, the fine-grained units may yield substantial quantities of water over time in areas where water levels have declined in surrounding coarse-grained units. All these units constitute the alluvial aquifer system. 
Hydrogeologic Framework

完

\begin{tabular}{|c|c|c|c|c|c|c|c|c|}
\hline 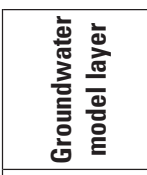 & - & $\sim$ & $m$ & $\nabla$ & in & 0 & $r$ & $\infty$ \\
\hline 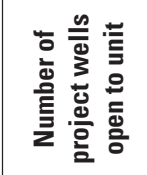 & in & $\stackrel{n}{m}$ & fo & $\infty$ & - & \multicolumn{3}{|c|}{ ? } \\
\hline 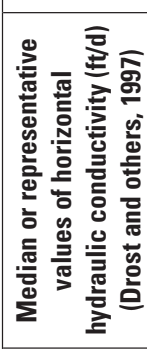 & $\underset{\infty}{\infty}$ & $\hat{i}$ & $\stackrel{\infty}{\triangle}$ & F & 1 & $\stackrel{\tilde{i}}{\mathrm{i}}$ & $=$ & \\
\hline 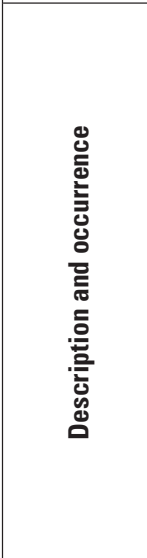 & 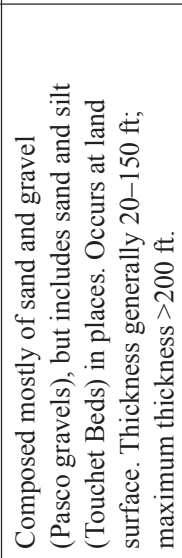 & 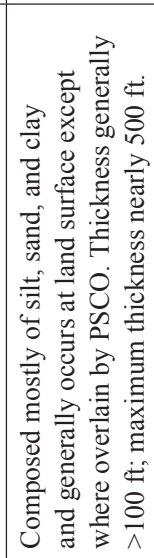 & 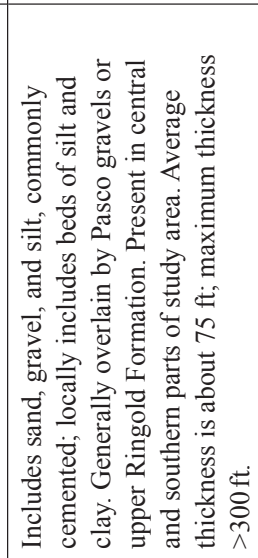 & 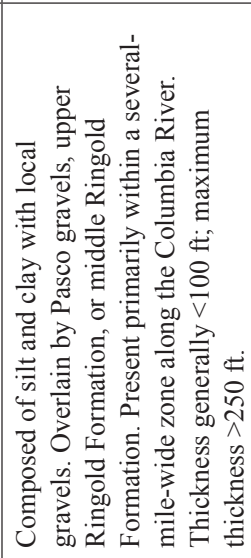 & 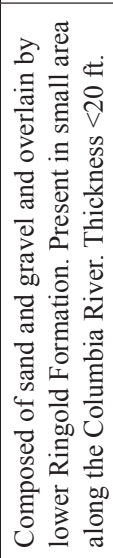 & 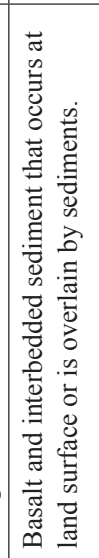 & 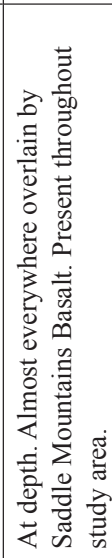 & 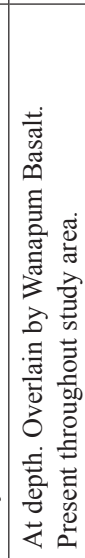 \\
\hline
\end{tabular}

is

它.

证

s.

की

흠

琼

萬离

竞 $\wedge$

ป 형

$\ddot{\bar{s}} \bar{y}$

颉

题通

क्षे

o

.

言产

कî

护

造

की

害

ठं $\sum^{2}$

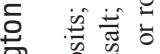

.
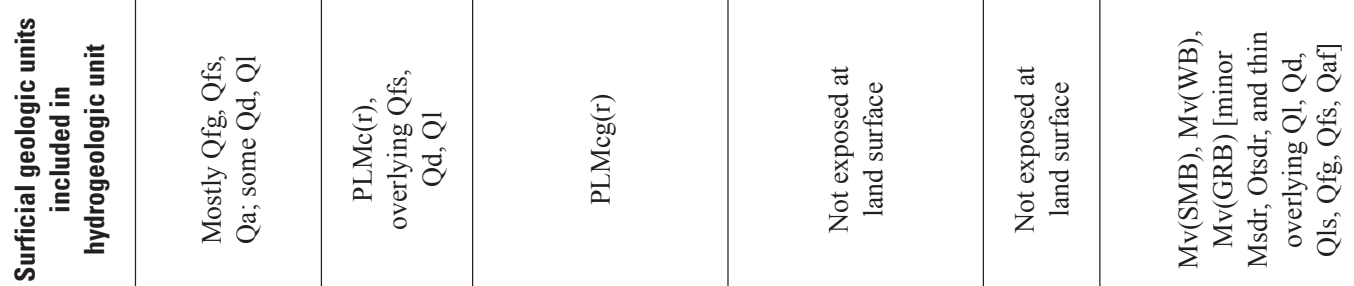

苟 可

ᄃ 竞空

峁 击

๘

$\stackrel{Ð}{ \pm}$

of:

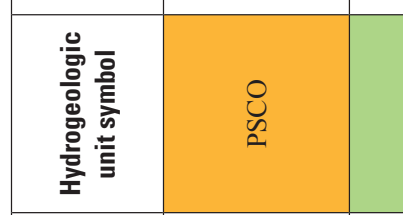

2

\begin{tabular}{|c|c|c|c|}
\hline 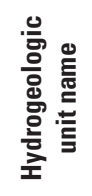 & 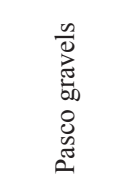 & 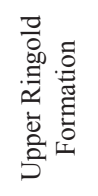 & 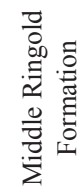 \\
\hline 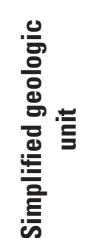 & 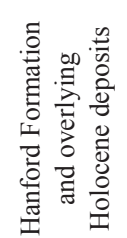 & & \\
\hline
\end{tabular}

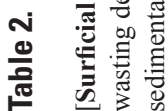

参

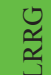

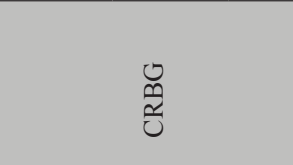

궁

要.

응

$\Xi$ \#

을 总焉

응

党

可

in is

政 


\section{Basalt Hydrogeologic Unit (CRBG)}

The Basalt hydrogeologic unit underlies the entire basin and occurs at land surface over about 40 percent of the study area, primarily in its high-altitude northern and eastern margins (pl. 1). The basalts form a complex series of aquifers and confining units at depth in the study area, in which most groundwater movement occurs in zones between basalt flows containing features such as flow breccia, rubble, and vesicles (Kahle and others, 2011). The principal basalt aquifer units in the study area are, from youngest to oldest, the Saddle Mountains Basalt, the Wanapum Basalt, and the Grande Ronde Basalt. Where it exists in the study area, the Saddle Mountains Basalt unit occurs at land surface or is overlain by younger sediment. The Wanapum Basalt unit generally is overlain by the Saddle Mountains Basalt and is present throughout most of the study area, except along Crab Creek (fig. 3). The Grande Ronde unit is present throughout the study area. The top altitude of the CBRG (fig. 6), which is based on the geologic map, project well logs, hydrogeologic sections, and the basalt altitude map of Drost and others (1997), was used for defining the base of the overburden and top altitude of the Saddle Mountains Basalt hydrogeologic unit. Manually drawn 100-ft contours of the basalt surface in the study area extent were combined with DEM land-surface altitudes where the basalt outcrops to generate a digital representation of basalt-surface altitude (fig. 6). The altitude of the basalt ranges from more than 2,600 ft in the Saddle Mountains to nearly $-50 \mathrm{ft}$ near the Columbia River. The top altitudes of the older and deeper Wanapum and Grande Ronde Basalt units were obtained from Burns and others (2011).

Of the project wells for which logs are available, 379 are completed in the basalt unit (table 2), where overlying sedimentary units do not occur, are insufficiently saturated, or are unable to yield sufficient quantities of water to wells. Four wells (16N/23E-12G01 through 16N/25E-06M01) that are depicted on the western end of section $C-C^{\prime}$ (pl. 1) are completed in basalt where overlying sediment either does not occur or is thin. In contrast, wells 13N/28E-09L01 and $13 \mathrm{~N} / 28 \mathrm{E}-11 \mathrm{E} 01$, which are depicted on the western side of section $E-E^{\prime}$ (pl. 1), penetrated more than $500 \mathrm{ft}$ of overlying fine-grained sediment (upper Ringold and lower Ringold Formation) before being completed in the basalt.

\section{Sedimentary Hydrogeologic Units}

Sedimentary hydrogeologic units, also referred to as overburden include all sediment that overlies the basalt, and primarily are part of the Ringold Formation. The thickness of this overburden (fig. 7) was calculated by subtracting the basalt-surface altitude (fig. 6) from the land-surface altitude. Overburden thickness is greatest (more than $840 \mathrm{ft}$ thick) in the center of the basin along the course of the Columbia River (fig. 7).

\section{Pasco Gravels Unit (PSCO)}

The Pasco Gravels unit is composed primarily of sand and gravel (the Pasco gravels), but includes sand and silt (Touchet Beds) in places. This unit occurs at land surface over about 32 percent of the study area (pl. 1). Lithologic data from 157 project wells completed in the Pasco gravels (table 2) indicate that Pasco gravels generally are $20-150 \mathrm{ft}$ thick. The thickest occurrence (more than $200 \mathrm{ft}$ ) of the unit is along the Wahluke Slope (section $D-D^{\prime}$, pl. 1).

\section{Upper Ringold Formation (UPRG)}

The upper Ringold Formation is composed primarily of silt, sand, and clay, and generally occurs at land surface except where overlain by the Pasco gravels. The unit occurs at land surface over about 26 percent of the study area (pl. 1). The upper Ringold commonly is about $200 \mathrm{ft}$ thick, but is more than $600 \mathrm{ft}$ thick on the western end of section $E-E^{\prime}$ (pl. 1). Despite being primarily fine-grained, 135 project wells are completed in the unit (table 2) and provide usable quantities of water.

\section{Middle Ringold Formation (MDRG)}

The middle Ringold Formation includes sand, gravel, and silt (commonly cemented), with interbeds of silt and clay in places. This unit is overlain by Pasco gravels or upper Ringold Formation, and is not known to occur at land surface in the study area. It occurs only in the central and southern parts of the study area (sections $A-A^{\prime}, D-D^{\prime}, F-F^{\prime}$, and $G-G^{\prime} ;$ pl. 1). Thickness averages about $75 \mathrm{ft}$, but it is more than $300 \mathrm{ft}$ thick beneath the Wahluke Slope (section $A-A^{\prime}, \mathrm{pl}$. 1). Forty-six of the project wells are completed in the middle Ringold Formation (table 2).

\section{Lower Ringold Formation (LRRG)}

The lower Ringold Formation is composed of silt and clay with gravel lenses, and is similar to and difficult to distinguish from the upper Ringold Formation using well logs. It does not occur at land surface and is overlain either by the Pasco gravels, upper Ringold Formation, or middle Ringold Formation. It occurs primarily in a several-mile-wide zone along the Columbia River where thicknesses generally are less than $100 \mathrm{ft}$, but occasionally approach $250 \mathrm{ft}$. Only eight project wells are completed in this unit (table 2).

\section{Basal Ringold Formation (BSRG)}

The basal Ringold unit is composed of sand and gravel and is overlain by the lower Ringold Formation. It occurs only in a small area along the Columbia River and generally is less than $20 \mathrm{ft}$ thick (section $E-E^{\prime}, \mathrm{pl}$. 1). Only one project well is completed in this unit (table 2). 


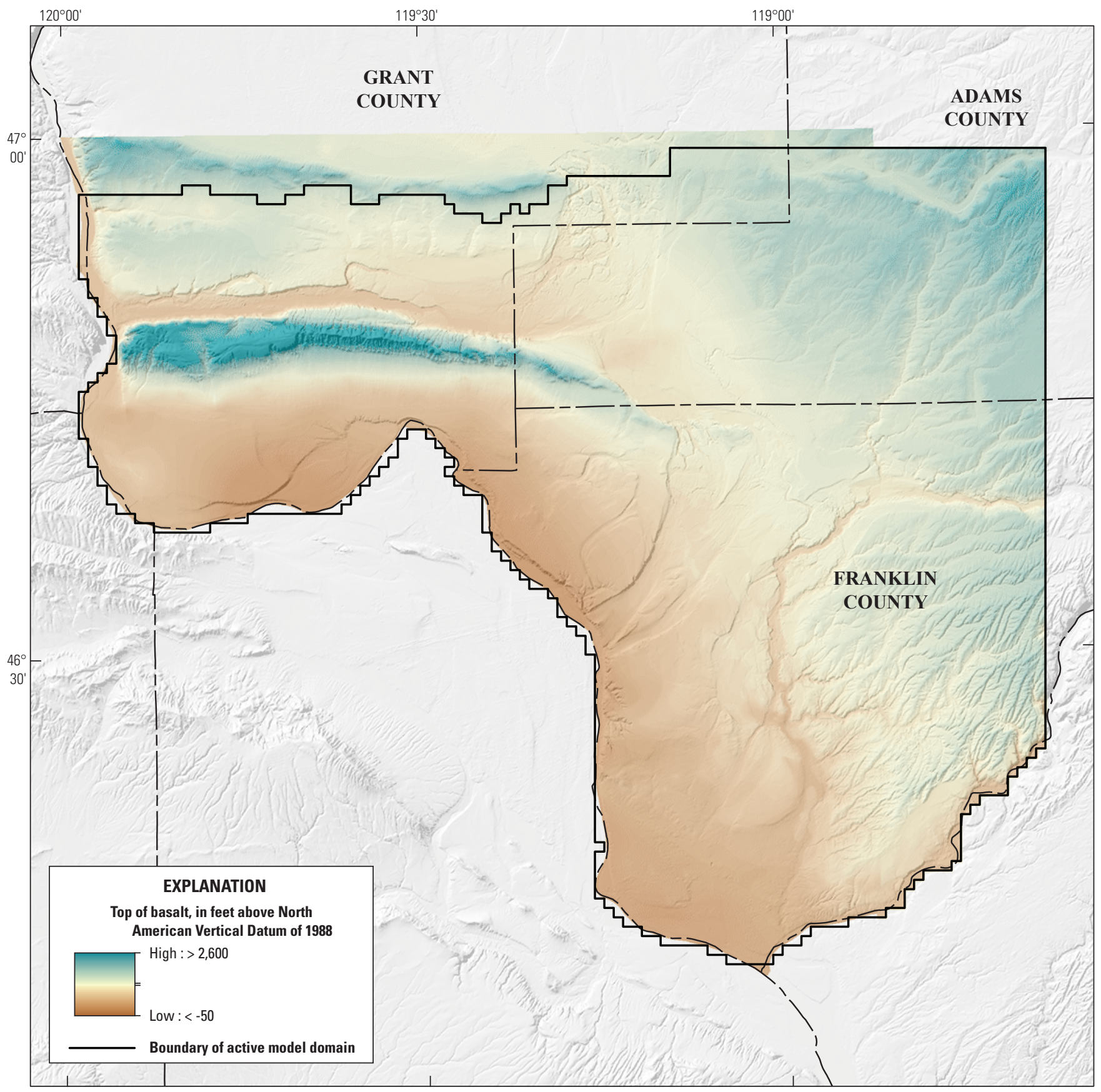

Elevation data from the National Elevation Dataset.

Washington State Plane South, FIPS zone 4602, units in feet.

Horizontal datum is North American Datum of 1983.

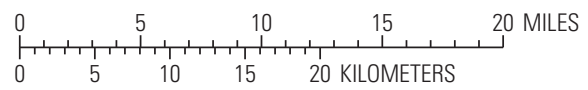

Figure 6. Top altitude of basalt surface, eastern Pasco Basin, Washington. 


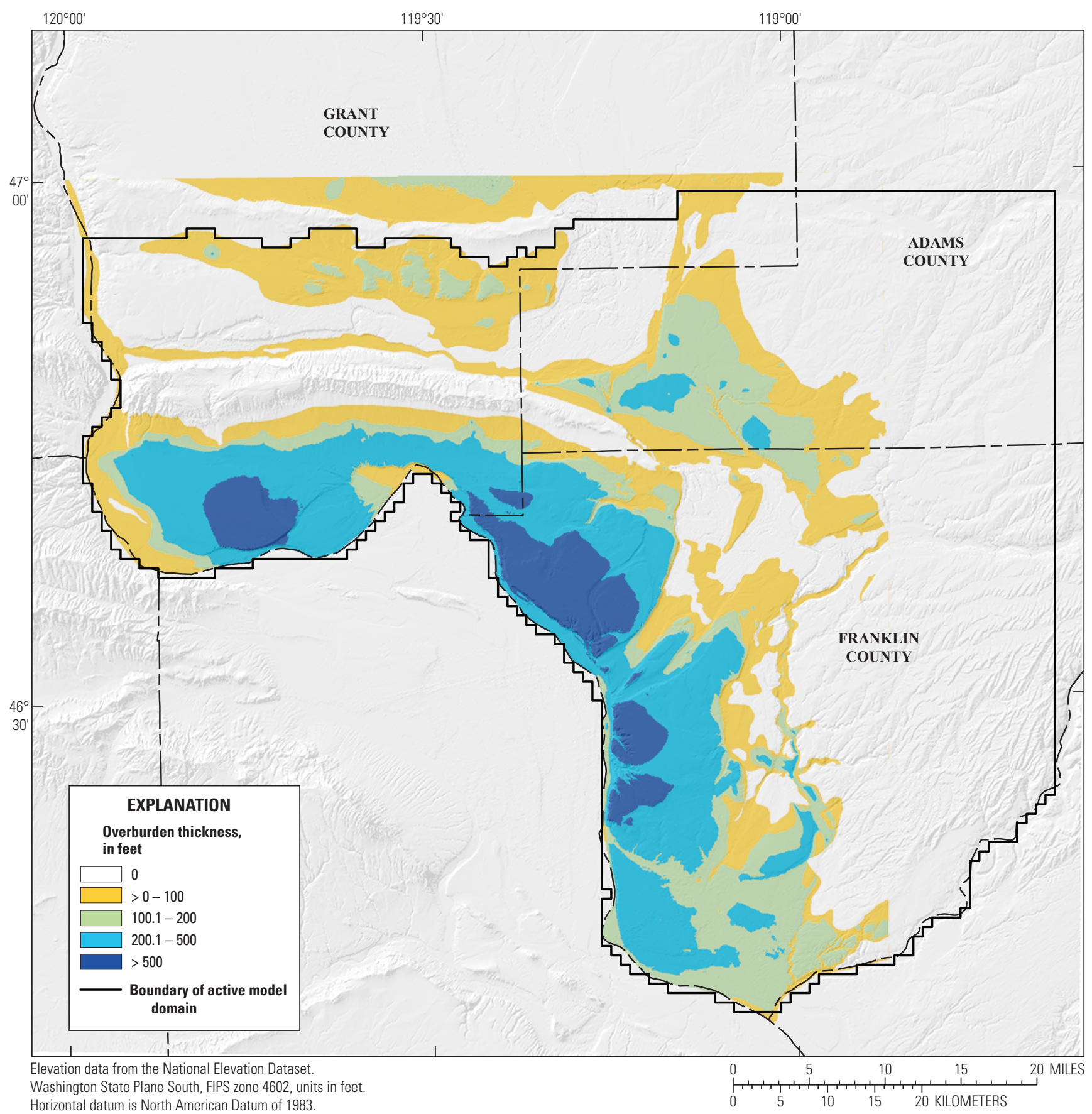

Figure 7. Extent and thickness of combined overburden units, eastern Pasco Basin, Washington.

\section{Hydraulic Properties}

Previous studies of hydrogeologic units in the Pasco Basin have measured or estimated values of horizontal hydraulic conductivity (K) and storage coefficient (S) or specific yield $\mathrm{S}_{\mathrm{y}}$ ). Values of these properties compiled from reference documents are summarized in table 3.
Whereas some previous studies reported storage coefficient values $(\mathrm{S})$ for confined aquifers, in this study the storage properties of confined hydrogeologic units were specified with specific storage $\left(\mathrm{S}_{\mathrm{s}}\right)$, which, when multiplied by the hydrogeologic-unit thickness (b), is transformed to a storage coefficient $\left(\mathrm{S}=\mathrm{S}_{\mathrm{s}} \times \mathrm{b}\right)$. 


\section{Hydrologic Setting}

\section{Recharge}

Prior to the 1950 s, deep infiltration of precipitation was the primary source of groundwater recharge in the study area. Since the early 1950s, irrigation return flows have become a substantial source of additional groundwater recharge beneath agricultural areas in the eastern Pasco Basin. The spatial distribution and temporal variation of recharge from precipitation and irrigation return flow to the Columbia Plateau Regional Aquifer System have been quantified using a monthly SOil WATer (SOWAT) balance model (Kahle and others, 2011). The SOWAT model uses simple relations among climatic, soils, land cover, and irrigation data to compute irrigation requirements and surplus moisture available for recharge. The SOWAT model incorporated evapotranspiration estimates derived from remotely sensed land-surface temperature data that were combined with other spatially distributed datasets including precipitation, soil moisture storage, and irrigation practices (Kahle and others, 2011).

\section{Recharge from Canal Leakage}

An extensive canal system (fig. 3) transports water diverted from the Columbia River to supply irrigation requirements in the Pasco Basin. Drost and others (1997) estimated that the recharge resulting from seepage losses from these canals was about 170,000 acre-ft/yr in the area of his study, which encompassed about 30 percent of the area in this study.

\section{Rivers}

Because the Columbia and Snake Rivers occupy the lowest-altitude regions in the study area, most groundwater that flows through the overburden sediments and shallow basalt flows in the Pasco Basin ultimately discharges to the Columbia or Snake Rivers. In local areas where the river stage is greater than the adjacent aquifer head, water from these rivers also may infiltrate the aquifer system. Infiltration from the river to the aquifer can occur upstream of the dams on the Columbia and Snake Rivers, and increased discharge back to these rivers likely occurs downstream of the dams (fig. 3). The completion of McNary Dam (not shown in fig. 3) in 1954 created Lake Walula on the Columbia River and a consequent rise in the groundwater base level at the southern end of the study area. Farther upstream on the Columbia River, the Wanapum and Priest Rapids Dams were completed in 1963 and 1961, respectively. On the Snake River, Ice Harbor Dam was completed in 1962.

\section{Agricultural Drains}

To control shallow groundwater levels, about $936 \mathrm{mi}$ of agricultural drains were buried in the South Columbia Basin Irrigation District in Franklin County (fig. 3) from 1964 through 1988, with installation peaking in 1976 (Drost and others, 1997). About 76,000 acre-ft/yr $\left(9,063,819 \mathrm{ft}^{3} / \mathrm{d}\right)$ of water estimated to be collected from these drains is routed to irrigation wasteways in the area studied (fig. 4; Drost and others, 1997).

\section{Springs}

Groundwater discharges to six springs along the White Bluffs along the Columbia River (fig. 3). The mean annual discharge at these springs ranges from about 290 acre-ft/yr $\left(34,560 \mathrm{ft}^{3} / \mathrm{d}\right)$ at Rankin Springs to 46,366 acre-ft/yr $\left(5,529,600 \mathrm{ft}^{3} / \mathrm{d}\right)$ at Ringold Springs; the total measured discharge rate from the springs was about 49,000 acre-ft/yr (5,883,840 ft $3 / \mathrm{d})$ during 1986-87 (Drost, 1997).

\section{Historical Groundwater Levels}

Water levels measured during 1939-45 in wells screened in both overburden sediments and underlying basalt aquifers (fig. 8) may be considered representative of the pre-development conditions that were present before the construction of surface-water delivery infrastructure or substantial groundwater withdrawals. During that period, the horizontal directions of groundwater flow generally were perpendicular to water-level altitude contours shown in figure 8. Groundwater flowed southwestward from high-altitude areas in the northeastern part of the study area toward the Columbia and Snake Rivers. Because water-level gradients could differ between the overburden and basalt aquifers, the directions of pre-development groundwater flow in both overburden and basalt aquifers might not be perpendicular to the contours in figure 8 for all areas. Water levels in the basalt and overburden aquifers began to rise substantially following the development of surface-water delivery infrastructure and associated agricultural irrigation in the early 1950 s. A hydrograph depicting a 270 -ft waterlevel rise (fig. 8B) from 1957 to 1970 exemplifies the change in water levels measured beneath irrigated areas where both basalt and the upper Ringold Formation occur. 


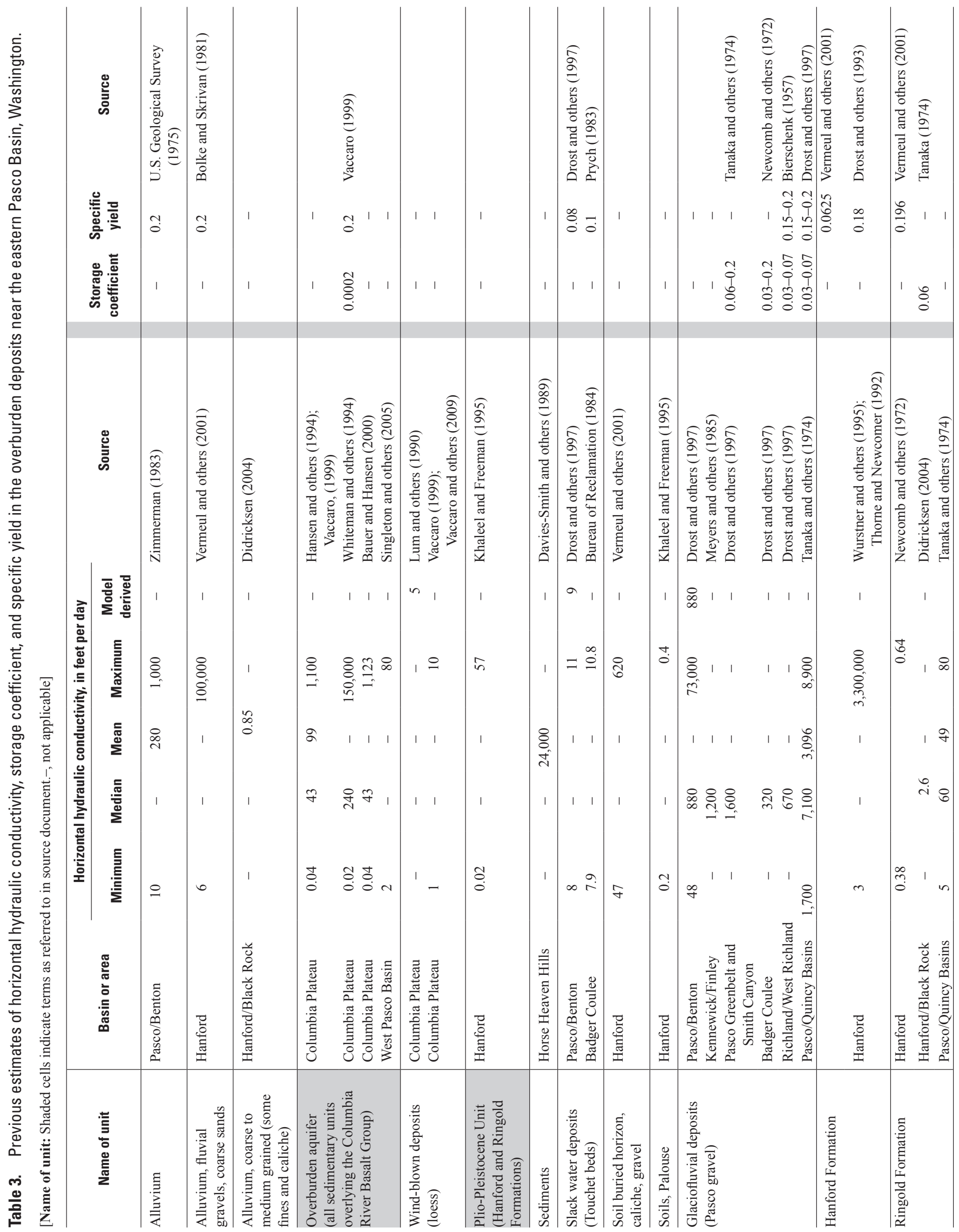




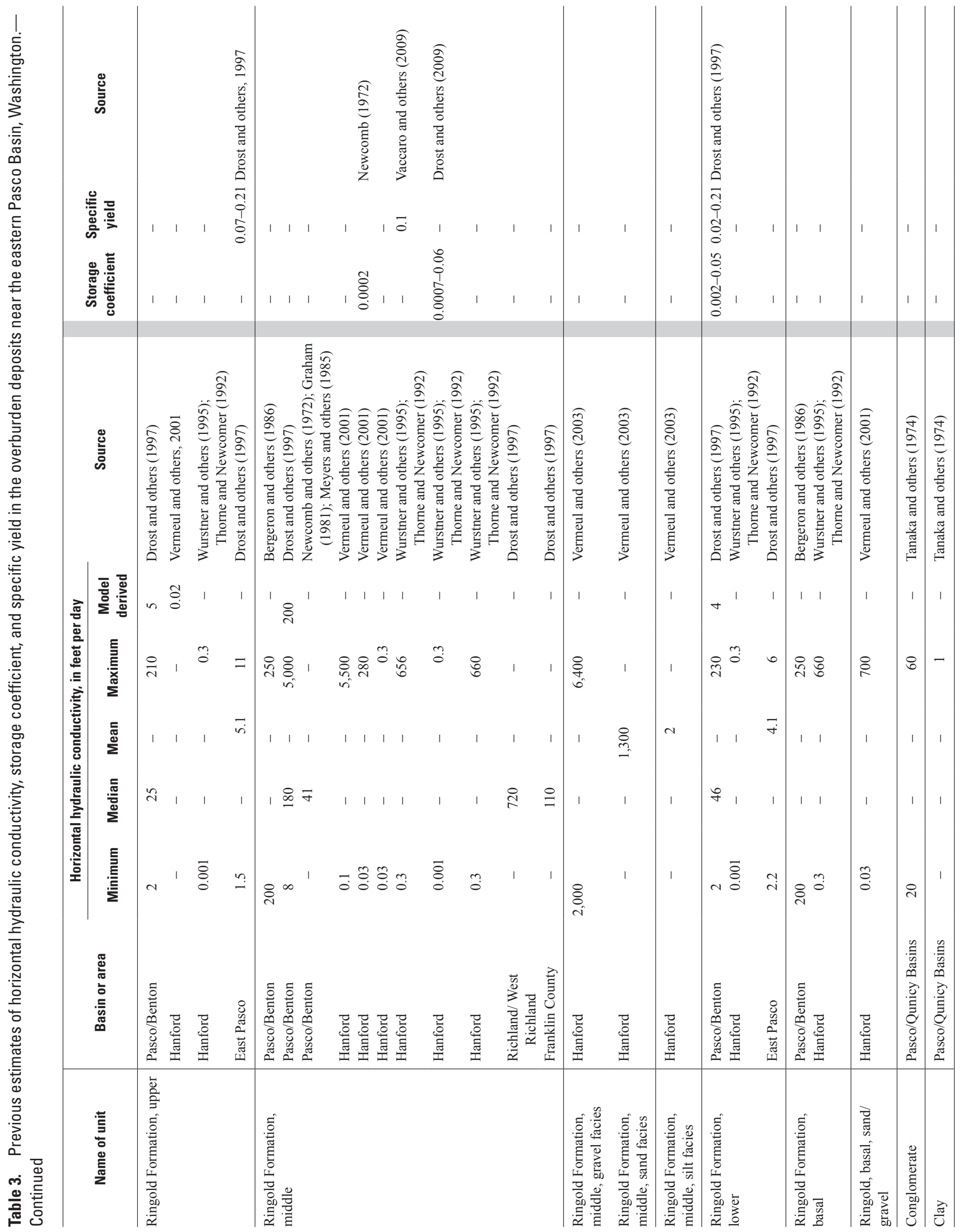




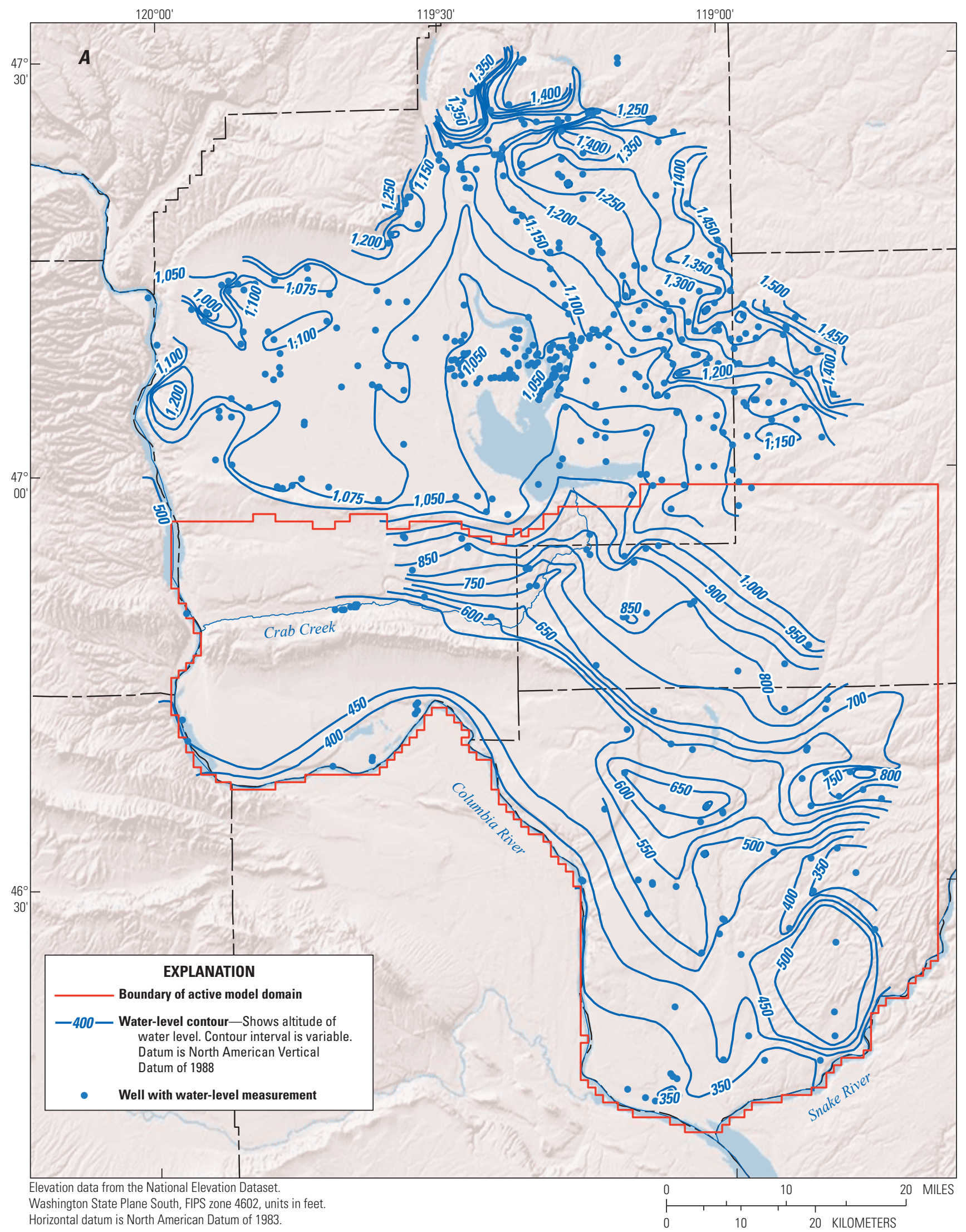

Figure 8. Water-level altitudes in wells, 1939-45 $(A)$ and hydrograph of well at location $B$ shown in figure $21(B)$, eastern Pasco Basin, Washington. 


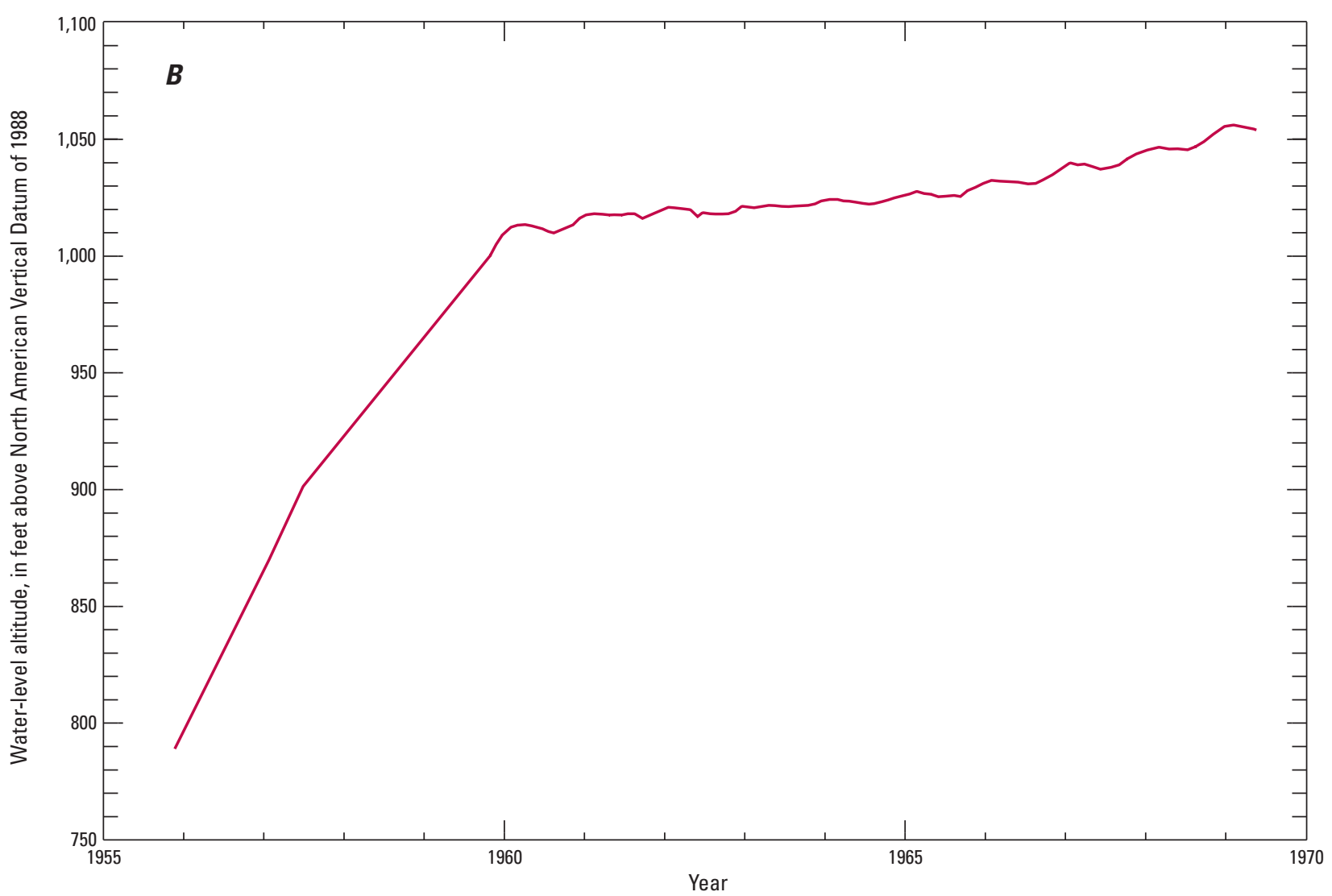

Figure 8.-Continued

\section{Simulation of Groundwater Flow}

The groundwater model is based on a simple conceptual model in which natural precipitation and irrigation return flow recharge the aquifer system by vertical flow through sedimentary overburden (where sediments occur) and into basalt layers. Regional groundwater flow through basalt aquifer layers occurs from areas to the north and east of the model domain and generally discharges to the Columbia or Snake Rivers, although flow through the deepest basalt layers may discharge farther away. The model was designed to address a primary project objective - quantification of the spatial distribution of additional groundwater in storage resulting from agricultural development. The model also can be used to address secondary project objectives, which include assessments of various pumping scenarios on groundwater levels, and, in particular, the pumping required to sufficiently lower groundwater levels in areas where high water levels may have increased the susceptibility to landslides.

\section{Modeling Strategy}

Recharge and groundwater withdrawals are major components of the groundwater budget, and although reasonable estimates of their magnitude and distribution are available from the previous SOWAT model, the location, depth, and magnitude of actual groundwater withdrawals remain substantially uncertain. Because records of actual groundwater withdrawals are not available, the SOWAT estimated withdrawals were assigned to aquifer intervals according to available well-screen data. In groundwater systems, the groundwater flux and hydraulic conductivity are correlated. Because of the necessity of specifying uncertain groundwater-withdrawal fluxes, relatively uniform hydraulic-conductivity distributions were simulated to avoid overfitting the water-level measurements during calibration. 


\section{Numerical Method}

Simulation of a substantially rising water table, such as that which occurred in the Pasco Basin between 1950 and 1986, involves rewetting nonlinearities and associated numerical instabilities with most versions of MODFLOW. The Newton formulation of the unconfined groundwater-flow equation available in MODFLOW-NWT (Niswonger and others, 2011) facilitates simulation of these systems, and, therefore, was selected to simulate groundwater flow in the eastern Pasco Basin.

\section{Spatial Discretization}

The model grid contains 87 rows and 105 columns of square finite-difference cells that are $1 \mathrm{~km}$ on a side (fig. 9). The grid was positioned so that the model cells correspond with the rasterized SOWAT model recharge and groundwaterwithdrawal data used to specify historical flows into and out of the model domain. The active model domain is north of the Columbia and Snake Rivers, and encompasses 2,192 $\mathrm{mi}^{2}$, or about 62 percent of the area covered by the rectangular finite-difference grid. Eight model layers (table 2) represent the five hydrogeologic units in the sedimentary overburden and the three basalt units underlying them. The thicknesses of individual model layers vary spatially to represent the thickness of the Pasco Gravel, upper Ringold Formation, middle Ringold Formation, lower Ringold Formation, basal Ringold Formation, Saddle Mountains Basalt, and Wanapum Basalt. The upper $100 \mathrm{ft}$ of the Grande Ronde Basalt is represented by the lowest model layer. Although the eight model layers generally correspond to these hydrogeologic units, the sedimentary hydrogeologic units do not occur in all areas of the model domain. In order to simulate hydraulic connection between hydrogeologic units where a stratigraphically intervening hydrogeologic unit is not present, the absent units were assigned a 1-ft layer thickness so that all layers are represented everywhere in the active model domain.

\section{Time Discretization}

A steady-state stress period was used to simulate groundwater conditions in the Pasco Basin prior to 1920. Ninety-four annual stress periods encompass the time interval from January 1, 1920, through December 31, 2013, that was used for calibration to measured water levels. Seven additional annual stress periods from January 1, 2014, through December 31, 2020, span the time interval of the four groundwater-management scenarios that are described in section, "Scenarios." Because of the uncertainty in the specification of boundary conditions representing recharge and groundwater withdrawals, additional numerical accuracy from multiple time steps in each stress period was not warranted, and a single time step was used for each annual stress period to simulate water levels and flows.

\section{Boundary Conditions}

Specified- and head-dependent flow boundary conditions were assigned along the spatial boundaries of the groundwater-flow system. Within the model domain, head-dependent flow boundaries were used to simulate rivers, drains, springs and groundwater-withdrawal wells.

\section{Specified Flow Boundaries}

Time-varying specified inflow through the top of the model simulated recharge to the water table. Except for the lateral parts of the model domain that simulate groundwater underflow with head-dependent flow boundaries (see section, "Head-Dependent Flow Boundaries"), the lateral and bottom surfaces of the model domain are no-flow boundaries.

\section{Recharge}

The annual recharge specified in the regional model of Ely and others (2014), which includes both natural and anthropogenic components, was used for the Pasco Basin model documented in this report. Although the regional model of Ely and others (2015) uses larger (3- $\left.\mathrm{km}^{2}\right)$ finite-difference cells, recharge for that model was computed with $1-\mathrm{km}^{2}$ raster arrays that are compatible with the $1-\mathrm{km}^{2}$ finite-difference cells of this model. Ely and others (2015) estimated natural recharge using gridded historical estimates of annual precipitation for 1895-2007. Pre-development recharge was estimated as the average natural recharge for this period. Irrigation recharge and irrigation pumping were estimated using a remote-sensing based SOWAT model for 1985-2007. Pre-1985 irrigation recharge and pumping were estimated using previously published compilation maps and the history of large-scale irrigation projects. The historical recharge estimated for 2007 (fig. 10) was specified for all subsequent years of the simulation. Because 2007 precipitation was similar to the mean annual precipitation (Kahle and others, 2011), extrapolation of the 2007 simulated recharge was a reasonable representation for subsequent years.

\section{Head-Dependent Flow Boundaries}

Groundwater flows to rivers, agricultural drains, natural springs, and across the northern and eastern model perimeter depend on the hydraulic heads of those features and the aquifer groundwater levels, and therefore, are simulated as head-dependent boundaries. Groundwater withdrawals simulated with the Multi-Node Well (MNW2) package of MODFLOW also are considered head-dependent flow boundaries because, although the total flow from each withdrawal well is specified, the distribution of each specified flow among model layers depends on the heads in cells connected to the well. 


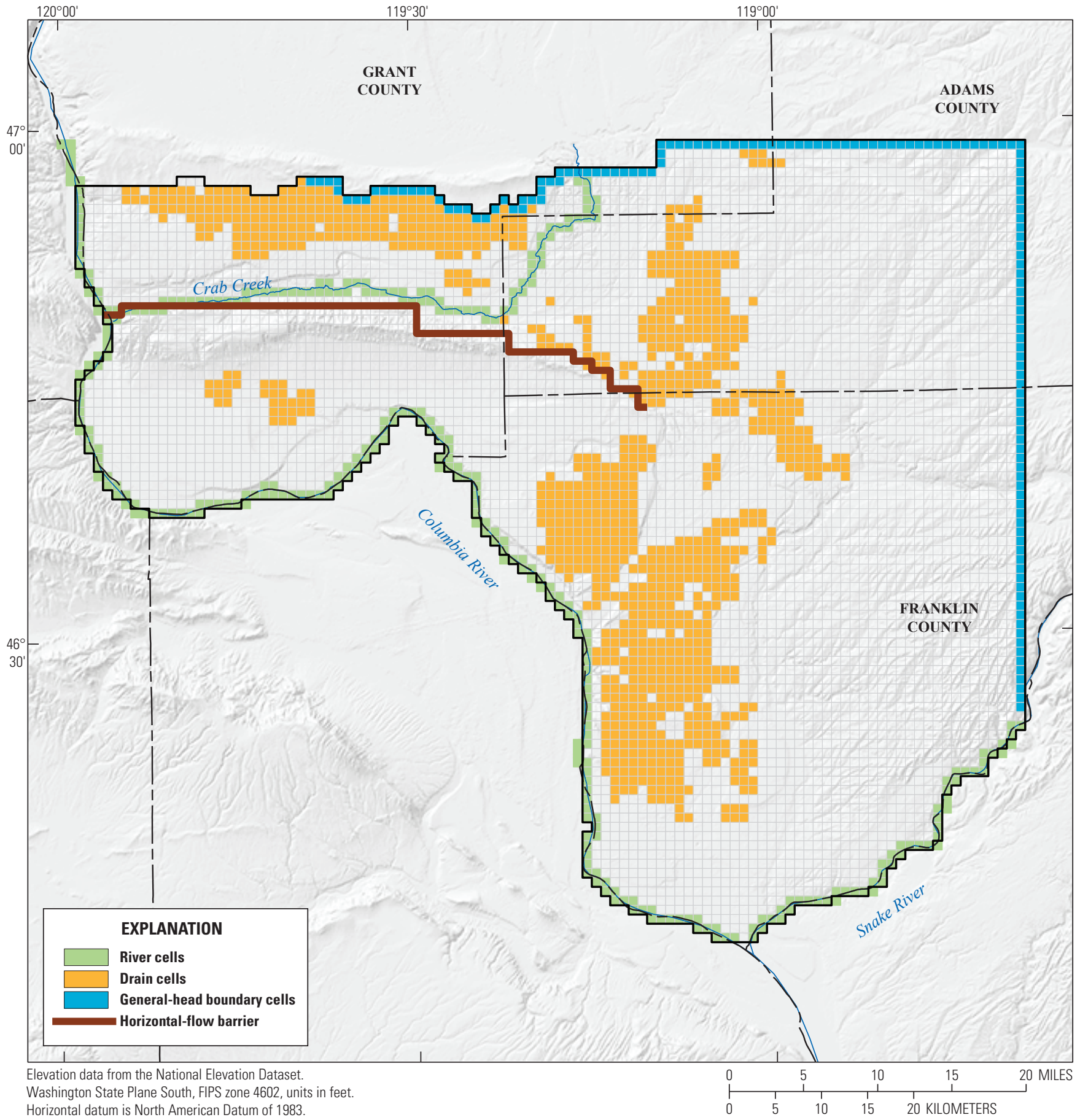

Figure 9. Finite-difference grid for the groundwater model with river and drain cells, general-head boundary cells, and horizontal-flow barriers, eastern Pasco Basin, Washington. 


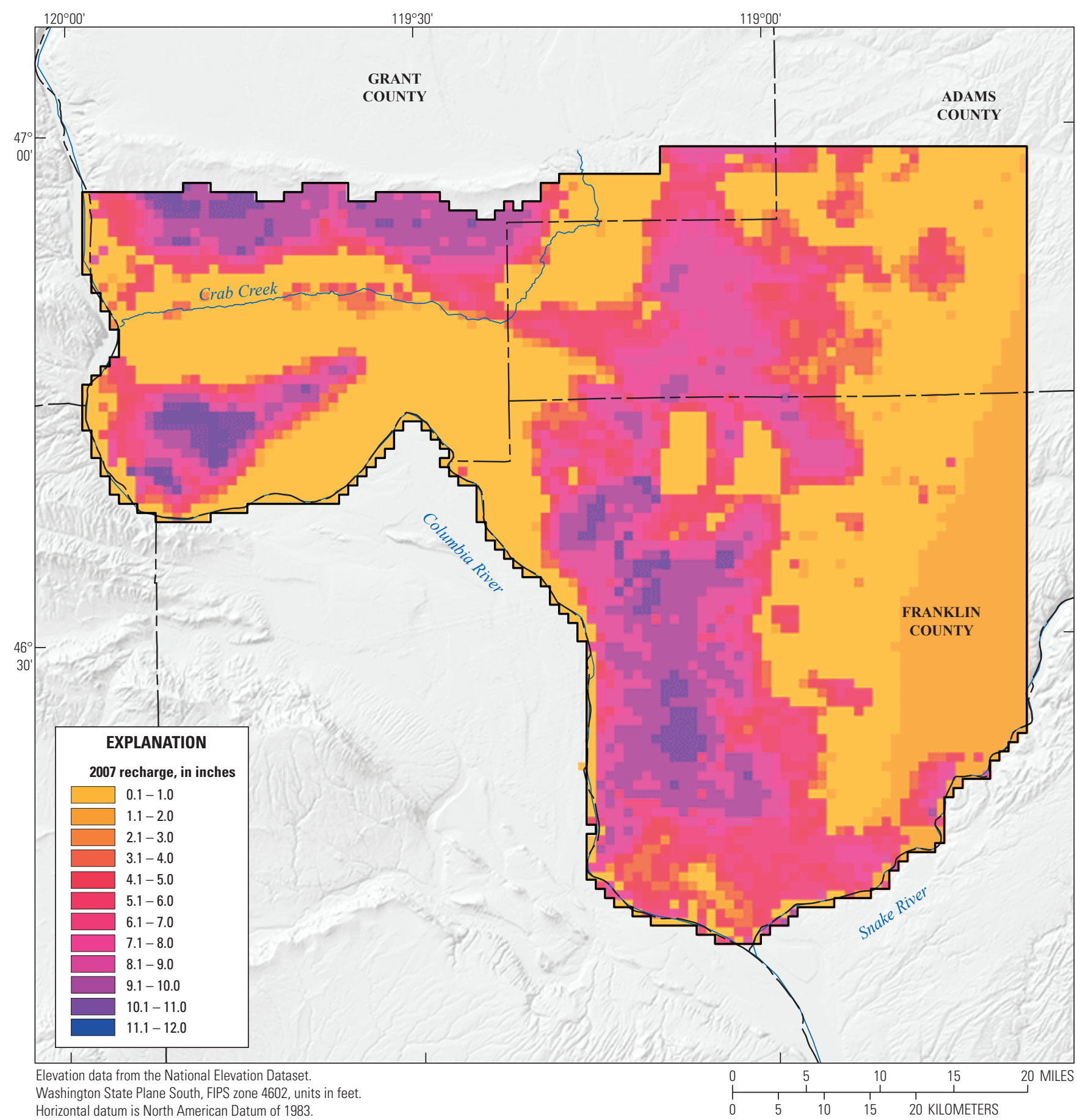

Figure 10. Distribution of recharge specified in the Pasco Basin model domain for 2007, eastern Pasco Basin, Washington. 


\section{Groundwater Underflow}

The flow of groundwater in the CRBG through the northern and eastern perimeter of the study area was simulated at the locations in figure 9 with the General Head Boundary (GHB) package of MODFLOW. The GHBs were connected to model layer 8, which represents the top $100 \mathrm{ft}$ of the Grande Ronde Basalt. Water levels specified for each of the GHBs were those simulated in layer 34 during the steady-state, pre-development stress period of the revised Columbia Plateau Regional Aquifer System (CPRAS) model (Ely and others, 2014) at the location corresponding to the GHB.

\section{Groundwater Withdrawals}

The groundwater withdrawals estimated with the SOWAT model were simulated with the MNW2 package. Assignment of the SOWAT model-estimated groundwater withdrawals to appropriate depths likely introduces the greatest errors in the model because records of the actual location and magnitude of withdrawals are not available. For each stress period, the groundwater withdrawal estimated by the SOWAT model for each model cell was assigned to one or more project wells (which have known screen-interval information, and are shown as "additional wells used in model" in figure 11) if a project well occurred in the cell. For cells with no project well, screen-interval information from a project well in a neighboring cell was used. If no project well was in a neighboring cell, the withdrawal was assigned across all aquifers above the total depth of a neighboring non-project well (fig. 11). Multiple variations of this type of assignment scheme were considered, all of which involve uncertainty in the depth and location of the withdrawal. Some structural model error, therefore, was a byproduct of the specification of these specified groundwater withdrawals.

The magnitude of groundwater withdrawals from the study area was negligible until the 1930s, when it increased to about 5,000 acre-ft/yr by 1945 (fig. 12). Withdrawal rates increased ten-fold over a 25 -year period from the early $1960 \mathrm{~s}$ through the late 1980s - from about 25,000 acre-ft/yr in 1963 to more than 250,000 acre- $\mathrm{ft} / \mathrm{yr}$ by the late $1980 \mathrm{~s}$.

\section{Drains}

Agricultural drains and springs were simulated with the Drain (DRN) package of MODFLOW. The total length of buried agricultural drains (fig. 3) in each model cell was used to specify hydraulic conductance from the model cell to each drain boundary. The drain-boundary altitudes were specified as the minimum DEM land-surface altitude in the model cell containing the drain. For cells in which the minimum DEM land-surface altitude was less than that of the top model layer, the drain boundary was connected to the underlying model layer that corresponded to the minimum DEM altitude.
Discharge to six springs (fig. 3) also was simulated with the MODFLOW DRN package. The simulated springs include Ringold Springs, Baxter Springs, WB5 Wasteway Springs, Savage Island Landslide Spring, Rankin Springs, and the Block 15 landslide. Because simulated drainflow is sensitive to the specified drain altitude, and the altitude of the springs was uncertain, simulated flow to most springs was not useful to model calibration, and the spring-flow observations were assigned a small weight in the calibration regression.

\section{Rivers}

The Columbia and Snake Rivers bound the western, southern, and southeastern sides of the model domain, and were simulated with the River (RIV) package of MODFLOW (fig. 9). The part of Crab Creek in the model domain also was simulated with the RIV package. The parts of the Columbia and Snake Rivers that border the model domain were simulated without dams prior to 1962 . For simplicity, stage changes on segments of these rivers due to construction of the Wanapum, Priest Rapids, McNary, and Ice Harbor Dams (fig. 3) were simulated to occur in 1962. The river stage, depth, and width at appropriate model cells were interpolated between actual measurement points along each river with the program RIVGRID (Leake and Claar, 1999).

\section{Hydraulic Property Distribution}

Parameters representing horizontal and vertical hydraulic conductivities, specific storage, and specific yield were assigned to each of the eight simulated hydrogeologic units. Heterogeneity of horizontal hydraulic conductivity in the Pasco gravels and Wanapum Basalt units was simulated by division of their spatial extents into three and two zones, respectively. The upper Ringold Formation was divided into six zones to enable simulation of possible heterogeneity of specific yield in that formation. Hydraulic conductivity of the other hydrogeologic units and specific storage in each hydrogeologic unit was uniform throughout the model domain.

\section{Horizontal Flow Barriers}

The Saddle Mountains Fault (Lidke, 2002) was simulated with horizontal flow barriers (HFBs; Hsieh and Freckleton, 1993) in all model layers at the locations shown in figure 9. The decreased hydraulic conductance between adjacent model cells is specified with a hydraulic characteristic for each HFB that is dimensionally equivalent to the hydraulic conductivity of the fault zone (in the direction perpendicular to the fault plane) divided by the width of the fault zone. A single hydraulic characteristic for HFBs representing the Saddle Mountains Fault barriers was parameterized and estimated during model calibration. 


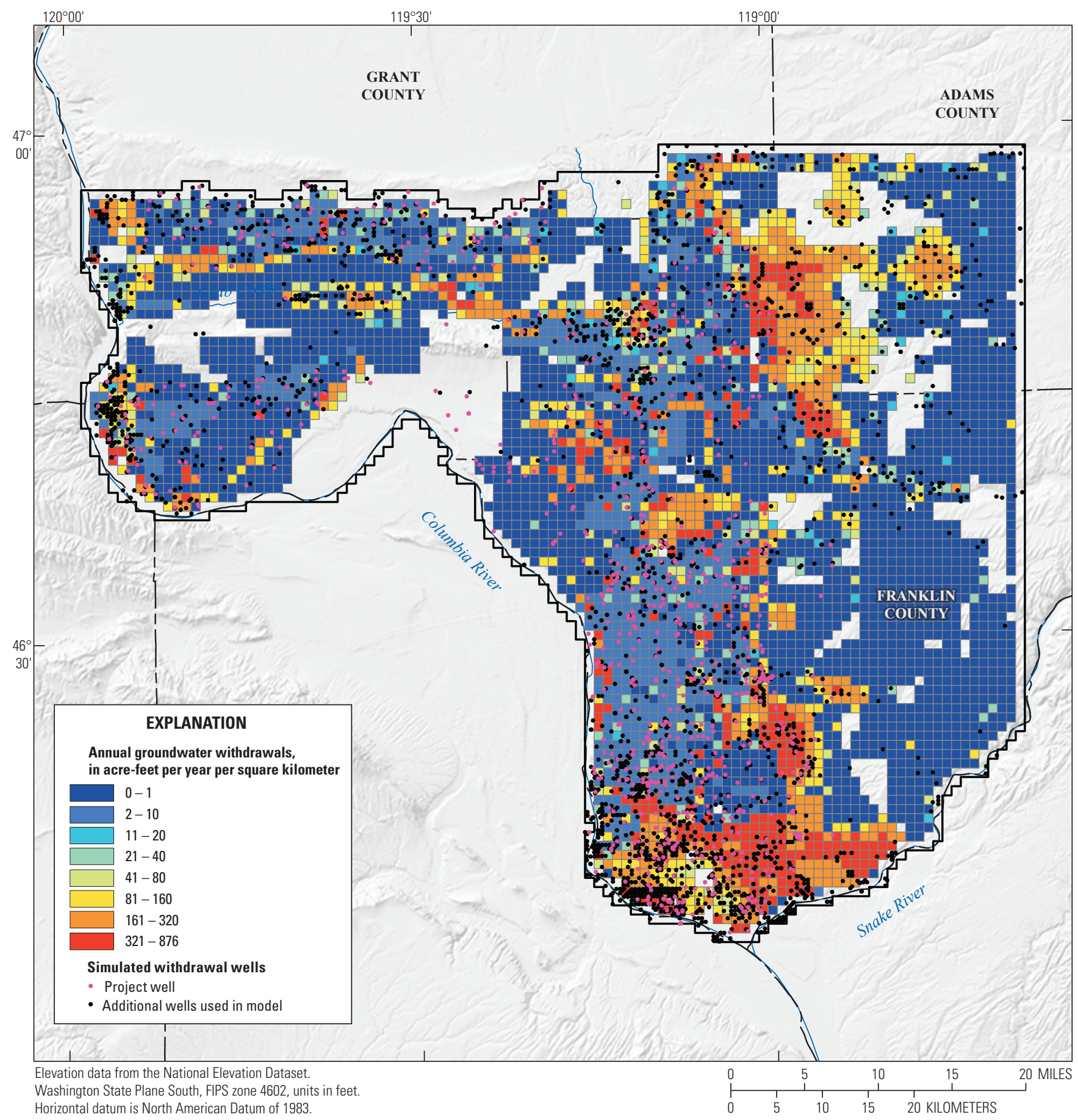

Figure 11. SOil WATer balance (SOWAT) model-estimated groundwater withdrawals for 2007 and locations of simulated withdrawal wells, eastern Pasco Basin, Washington. 


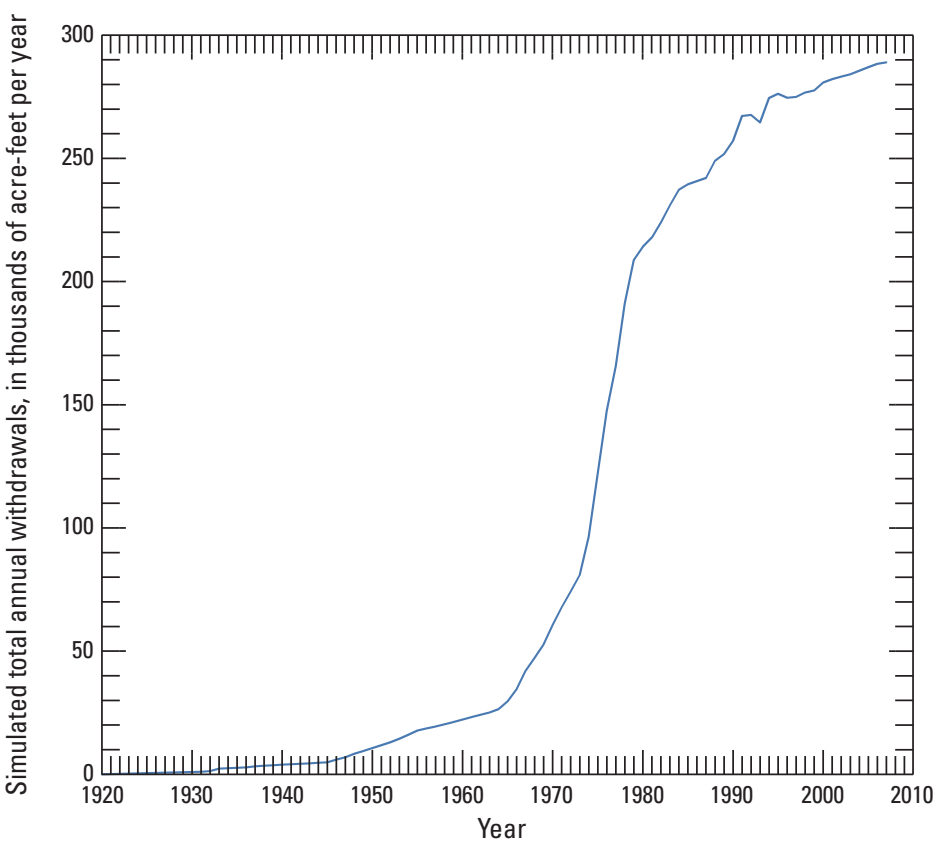

Figure 12. Simulated total annual groundwater withdrawals, eastern Pasco Basin, Washington

\section{Water-Level Measurements}

The model-calibration dataset included 7,559 water levels measured in the 726 project wells with screened interval information. Although only a single measurement was recorded from some wells, multiple measurements from most of the project wells constituted water-level hydrographs of as much as 46 years in duration (well 17N/26E-34D01 has the longest record). Almost one-half of the measurements $(3,289)$ were made in wells with screens that penetrated more than one hydrogeologic unit. For these multi-layer measurements, the proportion of the well screen connected to each model layer was specified in the Head-Observation (HOB) package of MODFLOW, which calculates an aggregate simulatedequivalent water level from these specified proportions. An additional 99 water-level measurements that were used to construct the map of pre-development water levels (fig. 8) also were specified to represent the 1939 water-table altitude in the HOB package.

\section{Model Calibration}

The model was calibrated with the parameter estimation code PEST++ (Welter and others, 2012), which adjusted the model parameters within specified reasonable limits to minimize the objective function (eq. 1) that quantifies differences between simulated water levels and flow rates and their measured values. The calibration uses 7,858 water-level measurements, which were classified either as heads or the head change from the initial head measured in each observation well. About 200 water levels were measured during the period corresponding to the steady-state stress period (1900-1920); the remaining water levels were measured after 1920. Because the assessment of change in groundwater storage is a model objective, it was important to accurately simulate changes in water levels. Accordingly, the regression equation (eq. 1) uses 826 water-level measurements as heads (the earliest water-level observation from each project well, plus the pre-development observations) and 7,032 water-level measurements as head changes, or the water-level change from the earliest water level measured in each well. The measured flow rates from six springs during 1986-87 and the estimated flow through agricultural drains reported by Drost (1997) also were used for calibration. 


$$
\begin{gathered}
\sum_{k=1}^{826}\left(\omega_{k} H_{k}-\omega_{k} H_{k}^{\prime}(\mathbf{b})\right)^{2} . \\
+\sum_{j=1}^{7032}\left(\omega_{j} D_{j}-\omega_{j} D_{j}^{\prime}(\mathbf{b})\right)^{2} \\
+\sum_{i=1}^{7}\left(\omega_{i} F_{i}-\omega_{i} F_{i}^{\prime}(\mathbf{b})\right)^{2}
\end{gathered}
$$

In equation 1, symbols in the first summation are associated with water levels,

where

$$
\begin{gathered}
826 \text { is the number of measurements used as } \\
\text { water-level heads, } \\
H_{k} \quad \text { is the measured water level for observation } k, \\
H_{k}^{\prime} \quad \text { is the simulated-equivalent water level for } \\
\text { observation } k, \\
\omega_{k} \quad \text { is the weight applied to water-level } \\
\text { measurement } H_{k} \text { and its simulated } \\
\text { equivalent } H_{k}^{\prime} \text {, and } \\
\text { b is the vector of } 37 \text { model parameters. }
\end{gathered}
$$

Symbols in the second summation are associated with water-level measurements used as "drawdowns,"

where

$$
\begin{gathered}
D_{j} \quad \begin{array}{c}
\text { is the measured water-level drawdown for } \\
\text { observation } j,
\end{array} \\
D_{j}^{\prime} \quad \begin{array}{c}
\text { is the simulated-equivalent water-level } \\
\text { drawdown for observation } j, \text { and }
\end{array} \\
\omega_{j} \quad \begin{array}{c}
\text { is the weight applied to water-level } \\
\text { measurement } D_{j} \text { and its simulated } \\
\text { equivalent } D_{j}^{\prime}
\end{array}
\end{gathered}
$$

Symbols in the third summation are associated with measured or estimated flows,

where

$$
\begin{gathered}
F_{i} \quad \text { is the flow for observation } i, \\
F_{i}^{\prime} \quad \text { is the simulated-equivalent flow for } \\
\text { observation } i, \text { and } \\
\omega_{i} \quad \begin{array}{l}
\text { is the weight applied to water-level } \\
\text { measurement } F_{i} \text { and its simulated } \\
\text { equivalent } F_{i}^{\prime} .
\end{array}
\end{gathered}
$$

The weight $(\omega)$ assigned to water-level or flow observations should represent the measurement error, and typically is computed as the inverse of the total observation-error variance. Substantial differences in measurement errors of the water levels were not determined, and, therefore, were assumed to be equivalent, which resulted in uniform weighting among the water-level and drawdown-observations.
The calibrated values of 37 model parameters representing aquifer hydraulic conductivity, storage, and boundary and fault conductances are tabulated with their corresponding sensitivities (table 4). The calibrated values of hydraulic conductivity, storage coefficient, and specific yield are all within the range of values measured or estimated for their corresponding hydrogeologic units by previous studies (table 3).

\section{Parameter Sensitivities}

The composite parameter sensitivity represents the total amount of information provided by the water-level, drawdown, and flow observations for the estimation of the model parameter (Hill and Tiedeman, 2007). PEST++ computes a composite sensitivity of each model parameter with respect to all the weighted simulated heads, drawdowns, and flows. The composite sensitivities of parameters included in the regression computed at the final parameter values are summarized in table 4. Generally, parameters with sensitivities greater than about 0.1 were more accurately estimated and had correspondingly small confidence intervals. Parameters with composite-scaled sensitivities less than about 0.1 were more difficult to estimate and (or) had larger confidence intervals than parameters with larger sensitivities. Simulated water levels were sensitive to parameters representing the horizontal hydraulic conductivity of the Pasco gravels (kpas), the horizontal and vertical hydraulic conductivities of the Wanapum Basalt (k_wanapum1, vk_7), the specific yield of the Pasco gravels and most of the Ringold Formation $\left(\mathrm{s}_{\mathrm{y}}\right)$, specific storage (ss), conductance to boundaries representing agricultural drains (drain_1970), and groundwater underflow across the northern and eastern model perimeter (ghb).

\section{Simulated Water Levels}

The distribution of the measured versus simulated water-level altitudes (fig. 13) is not random about a 1:1 line; a cluster of simulated water levels below this line in the range of measured water levels between 300 and $500 \mathrm{ft}$ indicates that the model overpredicts water-level altitudes in some areas within this range. Conversely, a greater number of simulated water levels above this line for measured water levels more than 1,000 ft indicates that the model underpredicts water levels in some areas with high water levels. Some model bias is indicated by this deviation from a random residual distribution. 
Table 4. Parameter values and sensitivities for the calibrated groundwater-flow model for eastern Pasco Basin, Washington.

[Abbreviations: $\mathrm{ft}$, foot; $\mathrm{ft} / \mathrm{d}$, foot per day; $\mathrm{ft}^{2} / \mathrm{d}$, foot squared per day]

\begin{tabular}{|c|c|c|c|c|}
\hline Parameter type & Units & Parameter name & Calibrated value & Composite sensitivity \\
\hline Horizontal hydraulic conductivity & $\mathrm{ft} / \mathrm{d}$ & $\begin{array}{l}\text { k_not } \\
\text { k_pas_gra2 } \\
\text { k_pas35678 } \\
\text { k_pas_gra4 } \\
\text { k_upp_ring } \\
\text { k_mid_ring } \\
\text { k_low_ring } \\
\text { k_bas_ring } \\
\text { k_wanapum1 } \\
\text { k_wanapum2 } \\
\text { k_basalt }\end{array}$ & $\begin{array}{r}12.0 \\
328.6 \\
519.6 \\
4,245.9 \\
9.2 \\
13.6 \\
11.7 \\
10.0 \\
6.5 \\
98.8 \\
4.2\end{array}$ & $\begin{array}{l}0.0165 \\
0.2520 \\
0.1694 \\
0.2595 \\
0.0855 \\
0.0892 \\
0.0360 \\
0.0020 \\
0.3127 \\
0.0748 \\
0.1283\end{array}$ \\
\hline Vertical hydraulic conductivity & $\mathrm{ft} / \mathrm{d}$ & $\begin{array}{l}\text { vk_coarse } \\
\text { vk_1345 } \\
\text { vk_2 } \\
\text { vk_6 } \\
\text { vk_7 } \\
\text { vk_8 }\end{array}$ & $\begin{array}{l}4.49 \mathrm{E}-01 \\
9.04 \mathrm{E}-03 \\
2.88 \mathrm{E}-03 \\
3.92 \mathrm{E}-02 \\
2.85 \mathrm{E}-03 \\
1.41 \mathrm{E}-01\end{array}$ & $\begin{array}{l}0.0009 \\
0.1000 \\
0.6740 \\
0.0555 \\
0.8076 \\
0.0093\end{array}$ \\
\hline Specific yield & dimensionless & $\begin{array}{l}\text { sy_pgravel } \\
\text { sy_up_rin1 } \\
\text { sy_up_rin2 } \\
\text { sy_up_rin3 } \\
\text { sy_up_rin4 } \\
\text { sy_up_rin5 } \\
\text { sy_up_rin6 } \\
\text { sy_md_ring } \\
\text { sy_lo_ring } \\
\text { sy_12345 } \\
\text { sy_678 }\end{array}$ & $\begin{array}{l}0.20 \\
0.12 \\
0.20 \\
0.20 \\
0.20 \\
0.10 \\
0.19 \\
0.20 \\
0.20 \\
0.17 \\
0.01\end{array}$ & $\begin{array}{l}0.1676 \\
0.1553 \\
0.0617 \\
0.0951 \\
0.1246 \\
0.1011 \\
0.0643 \\
0.1982 \\
0.1285 \\
0.0291 \\
0.5442\end{array}$ \\
\hline Specific storage & $\mathrm{ft}^{-1}$ & ss & $1.00 \mathrm{E}-06$ & 0.1501 \\
\hline $\begin{array}{l}\text { Fault hydraulic } \\
\text { characteristic }\end{array}$ & day $^{-1}$ & hfb & $1.00 \mathrm{E}-05$ & 0.0404 \\
\hline Boundary conductance & $\mathrm{ft}^{2} / \mathrm{d}$ & $\begin{array}{l}\text { ringspring } \\
\text { other_sprg } \\
\text { drain_1970 } \\
\text { columbia_r } \\
\text { snake_rivr } \\
\text { crab_creek } \\
\text { ghb }\end{array}$ & $\begin{array}{r}769.5 \\
10.0 \\
1,125.2 \\
10.0 \\
10.0 \\
0.1 \\
1,000.0\end{array}$ & $\begin{array}{l}0.0021 \\
0.0155 \\
0.1589 \\
0.0001 \\
0.0001 \\
0.0176 \\
0.2145\end{array}$ \\
\hline
\end{tabular}




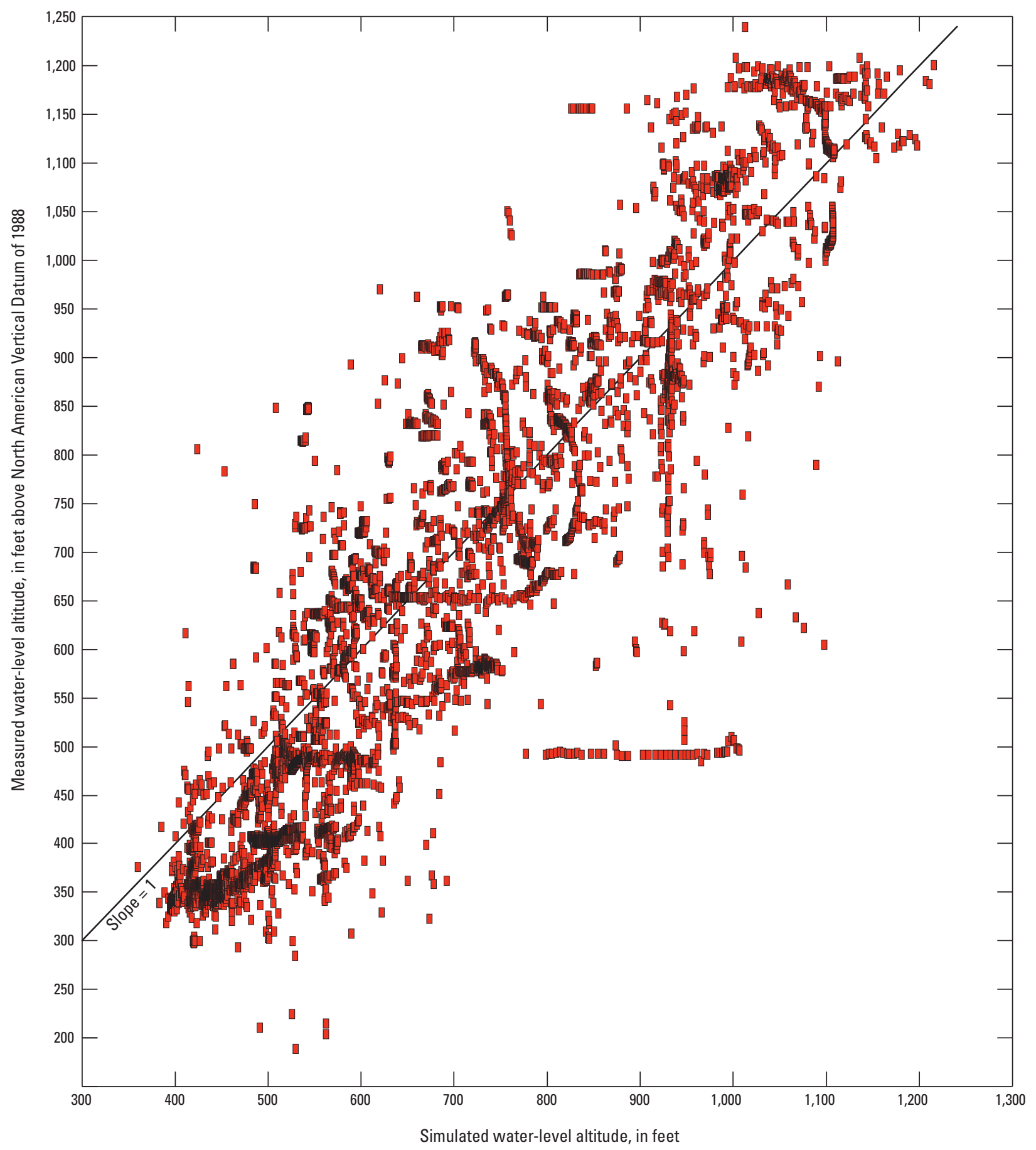

Figure 13. Measured and simulated water levels in the eastern Pasco Basin, Washington. 
To quantify the fit of simulated water levels to the 7,858 water-level measurements used for model calibration, summary statistics were calculated on the water-level residuals (measured minus simulated water-level altitudes). The mean magnitude of the water-level residuals was $84 \mathrm{ft}$. The rootmean-square error (RMSE) was calculated as the square root of the mean of the unweighted squared residuals:

$$
R M S E=\sqrt{\frac{\sum_{k=1}^{7,858}\left(H_{k}-H_{k}^{\prime}\right)^{2}}{7858}},
$$

where:

$$
\begin{gathered}
H_{k} \quad \begin{array}{l}
\text { is the measured water level for observation } k, \\
\text { and }
\end{array} \\
H_{k}^{\prime} \quad \begin{array}{l}
\text { is the simulated-equivalent water level for } \\
\text { observation } k .
\end{array}
\end{gathered}
$$

The RMSE and the standard deviation of the residuals were 105 and $101 \mathrm{ft}$, respectively. The normalized RMSE was 0.1 and was obtained by dividing the RMSE of the residuals by the 1,051-ft range of measured water levels. The mean error, calculated as the mean of the residuals (measured minus simulated water levels) was $-26.7 \mathrm{ft}$, indicating that overall simulated water levels are higher than measured water levels. The mean absolute error (mean of the absolute value of the residuals) was $84 \mathrm{ft}$.

The general directions of simulated groundwater flow during 2013 may be inferred from contours of simulated water-level altitudes for 2013 (fig. 14). In Grant County north of the Saddle Mountains, groundwater generally flows from high-altitude areas and discharges into Crab Creek. South of the Saddle Mountains, water flows from a central groundwater mound toward the Columbia River. In the northeastern part of the study area, groundwater generally flows from high-altitude areas in Adams County toward the southwest and the Columbia River. In Franklin County, groundwater flows south or southwest toward the Snake or Columbia Rivers.

The simulated rise in groundwater levels since 1920 in areas of the eastern Pasco Basin primarily is a function of the hydrogeologic units present and the magnitude of groundwater recharge in the area. Although groundwater withdrawals also affect water levels, their effect is difficult to discern because groundwater withdrawals are simulated in areas of high recharge. East of the Columbia River in Franklin County, water levels rose by more than $350 \mathrm{ft}$ by 2013 in two distinct mounds where the upper Ringold Formation is at or near land surface both north and south of Ringold Coulee (fig. 15), and simulated recharge is 5-10 in/yr (fig. 10). Similar mounding of recharged groundwater occurs where the upper Ringold Formation is at or near land surface in Adams County and Grant County north of the Saddle Mountains, and where the upper Ringold Formation subcrops beneath the Pasco gravels unit in Grant County south of the Saddle Mountains and in southern Franklin County (fig. 15). The high groundwater levels in these mounds partly result from the relatively low horizontal hydraulic conductivity of the upper Ringold sediments, which inhibits flow toward surrounding areas with lower groundwater levels. Water levels have not risen substantially in the Pasco gravels because their high hydraulic conductivity permits greater flow toward areas of groundwater discharge. Simulated water levels rose in basalt aquifers beneath cultivated areas (fig. 2) in Grant County north of the Saddle Mountains and eastern Franklin County where overburden sediments are not simulated. In the northeastern part of the model domain in Adams County where overburden sediments are not simulated (fig. 15), simulated water levels generally have risen by $50-100 \mathrm{ft}$, but also have declined by about $50 \mathrm{ft}$ in some areas with low recharge (fig. 10), presumably from groundwater withdrawals.

\section{Simulated Groundwater Budget}

The net flows (inflow minus outflow from the model domain) of groundwater-model components were calculated for each model stress period (fig. 16). Prior to 1946, variations in annual precipitation resulted in relatively modest changes in storage and net discharge to rivers. Note that increased groundwater storage is an outflow from the groundwater-flow system and is negatively signed; increasing negatively signed absolute values of storage in figure 16 indicate increases in the quantity of stored groundwater. Increased anthropogenic recharge from the late 1940s through the mid-1960s substantially increased groundwater storage in the aquifer system, and discharge to rivers approximately tripled by 1963 . Beginning in 1964, outflow to agricultural drains began to control rising water levels and associated increases in groundwater storage. Increasing groundwater withdrawals (pumpage) after 1964 further abated contributions to storage, and together with outflow to drains, somewhat decreased the outflow to rivers. Net changes to groundwater storage since 1984 have resulted primarily from variations in groundwater recharge caused by changes in annual precipitation.

The simulated groundwater budget in the 508-14 area calculated for the initial steady-state stress period (which represents average "pre-development" conditions from 1900 to 1920) and the last transient stress period (which represents 2013) are summarized in table 5. During 1900-1920, which is simulated with steady-state conditions, vertical recharge, lateral underflow, and some seepage from rivers into the 508-14 area were balanced by discharge to rivers and springs or lateral underflow out through the 508-14 boundary. By 2013, substantially more recharge into the area (compared to 1900-1920) resulted in increased discharge to rivers, springs, and drains, and increased net underflow out of the 508-14 area. The distribution of both recharge and groundwater withdrawals causes both increases and decreases in groundwater storage in different areas, which are summarized as outflows to and inflows from storage, respectively, in table 5. During 2013, a 9,000 acre-ft net decrease in groundwater storage was simulated for the 508-14 area. 


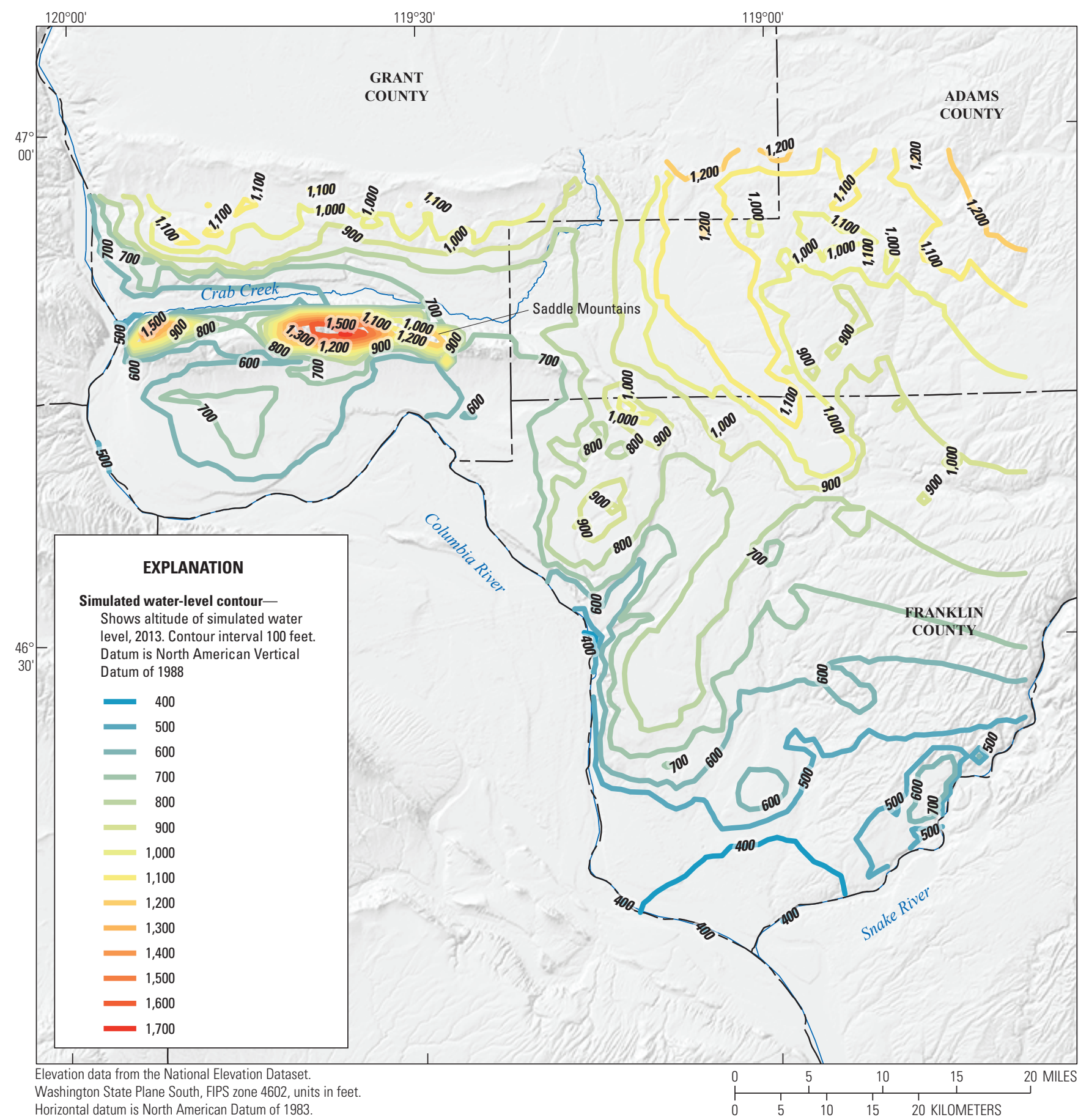

Figure 14. Simulated water-level altitudes, eastern Pasco Basin, Washington, 2013. 


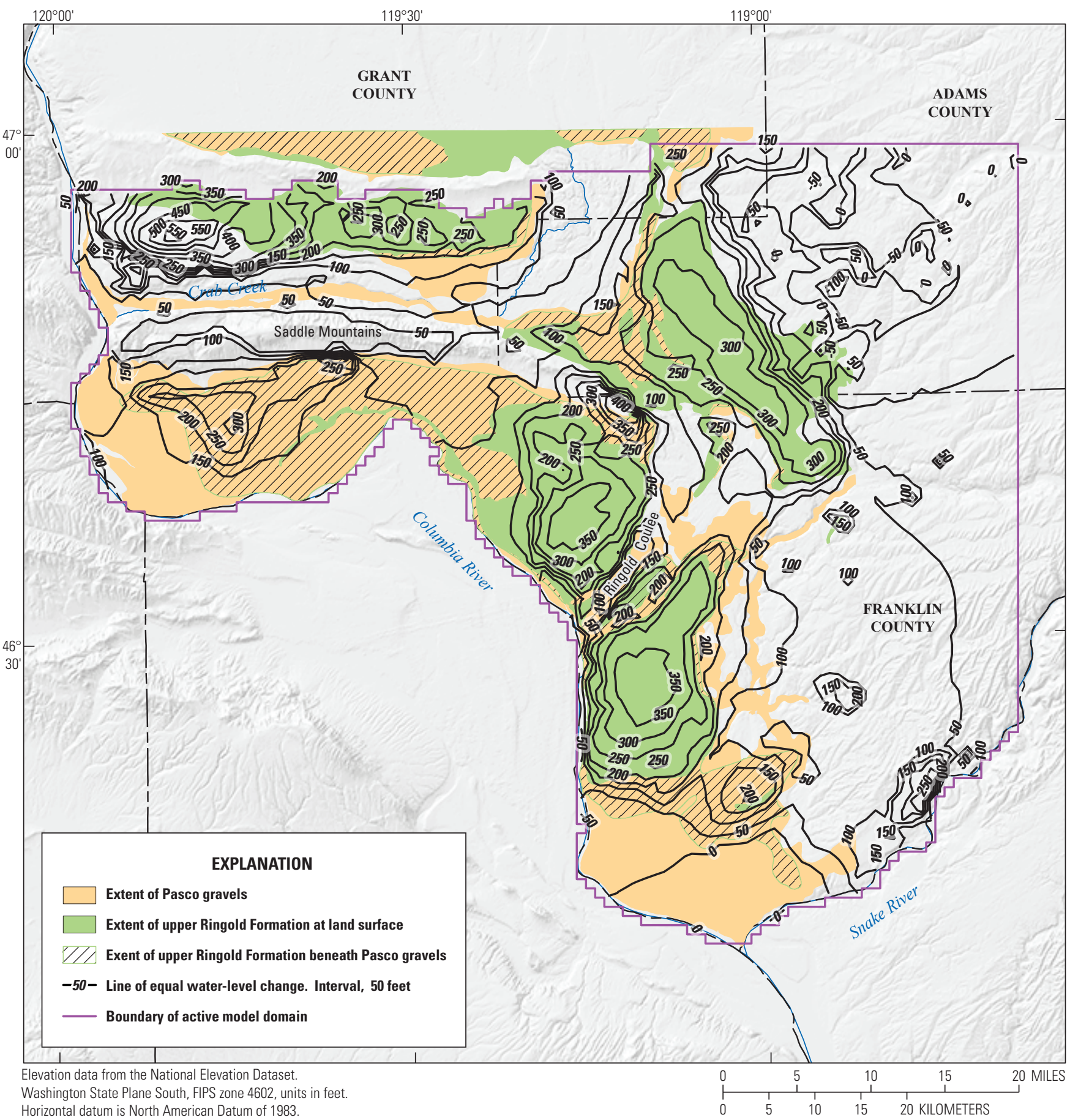

Figure 15. Simulated changes in water-level altitude, eastern Pasco Basin, Washington, 1920-2013. 


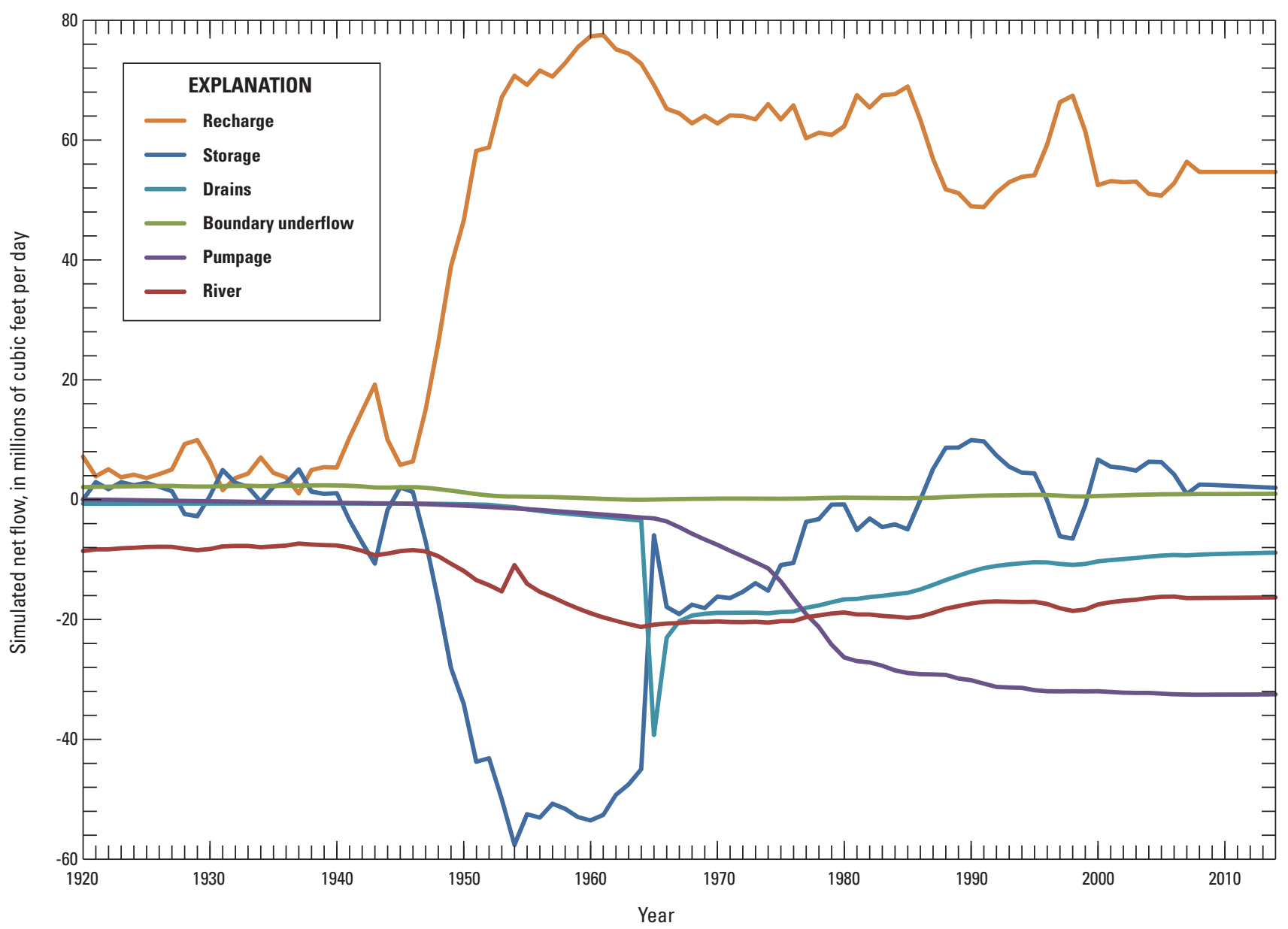

Figure 16. Simulated net flows into the groundwater model domain, eastern Pasco Basin, Washington, 1920-2013.

Table 5. Groundwater budget of the 508-14 area, eastern Pasco Basin, Washington, 1900-1920 and 2013.

[-, not applicable $]$

\begin{tabular}{|c|c|c|c|}
\hline & & $\begin{array}{c}1900-1920 \\
\text { (steady-state) } \\
\text { (thousands of } \\
\text { acre-feet per year) }\end{array}$ & $\begin{array}{c}2013 \\
\text { (thousands of } \\
\text { acre-feet per year) }\end{array}$ \\
\hline \multicolumn{4}{|l|}{ Inflow } \\
\hline Recharge & & 27 & 346 \\
\hline River leakage & & 5 & 2 \\
\hline Underflow & & 41 & 34 \\
\hline \multirow[t]{2}{*}{ Storage } & & - & 18 \\
\hline & Total & 73 & 400 \\
\hline \multicolumn{4}{|l|}{ Outflow } \\
\hline River leakage & & 40 & 105 \\
\hline Springs and drains & & 7 & 79 \\
\hline Underflow & & 25 & 60 \\
\hline Net withdrawals & & - & 147 \\
\hline Storage & & - & 9 \\
\hline & Total & 73 & 400 \\
\hline
\end{tabular}




\section{Simulated Storage Changes in the 508-14 Area}

The cumulative simulated change in storage through 2014 was summarized for the entire active model domain and five subareas (fig. 17) that compose the "508-14 area" (fig. 1) in which Ecology regulates groundwater withdrawals. Note that cumulative increases in groundwater storage are depicted as a positive quantity in figure 17, (in contrast to the negative rates of flow from the groundwater system into storage depicted in figure 16) To evaluate the effect of approving pending applications for groundwater-withdrawal permits, anthropogenic additions to storage (referred to as "artificially stored" groundwater by Ecology) must be quantified. The changes to groundwater storage in five subareas (fig. 18) of the
508-14 area are depicted with the total for the model domain (fig. 17), and net increases through 2013 are summarized (table 6). The additional groundwater in storage since the predevelopment period in the 508-14 area reached a maximum of 7.4 million acre-ft by 1985 and has since decreased by about 0.5 million acre- $\mathrm{ft}$ to a quantity of about 6.8 million acre- $\mathrm{ft}$ in 2013 (fig. 17). Whereas simulated storage changes stabilized or decreased after the late 1970s in most subareas, storage was simulated as continuing to increase in the west subarea through 2013. Simulated storage increases in the northwest subarea reached maximum levels in 1963, and decreased after drains were installed in 1964. Simulation of the installation of agricultural drains also decreased the rate of storage increases in the northeast, south, and central subareas.

Table 6. Net increase of stored groundwater in subareas of the 508-14 area, eastern Pasco Basin, Washington, 1920-2013.

[Values in thousands of acre-feet]

\begin{tabular}{|c|c|c|c|c|c|}
\hline \multirow{2}{*}{$\begin{array}{c}\text { Hydrogeologic } \\
\text { unit }\end{array}$} & \multicolumn{5}{|c|}{ Stored groundwater in the $508-14$ subarea } \\
\hline & Northwest & Central & West & Northeast & South \\
\hline Pasco & 33 & 23 & 383 & 38 & 191 \\
\hline Upper Ringold & 30 & 560 & 735 & 920 & 1,058 \\
\hline Middle Ringold & 3 & 5 & 744 & 12 & 413 \\
\hline Lower Ringold & 3 & 592 & 89 & 12 & 290 \\
\hline Basal Ringold & 3 & 5 & 4 & 12 & 10 \\
\hline Basalt & 201 & 99 & 83 & 147 & 131 \\
\hline Total & 273 & 1,284 & 2,038 & 1,141 & 2,093 \\
\hline
\end{tabular}




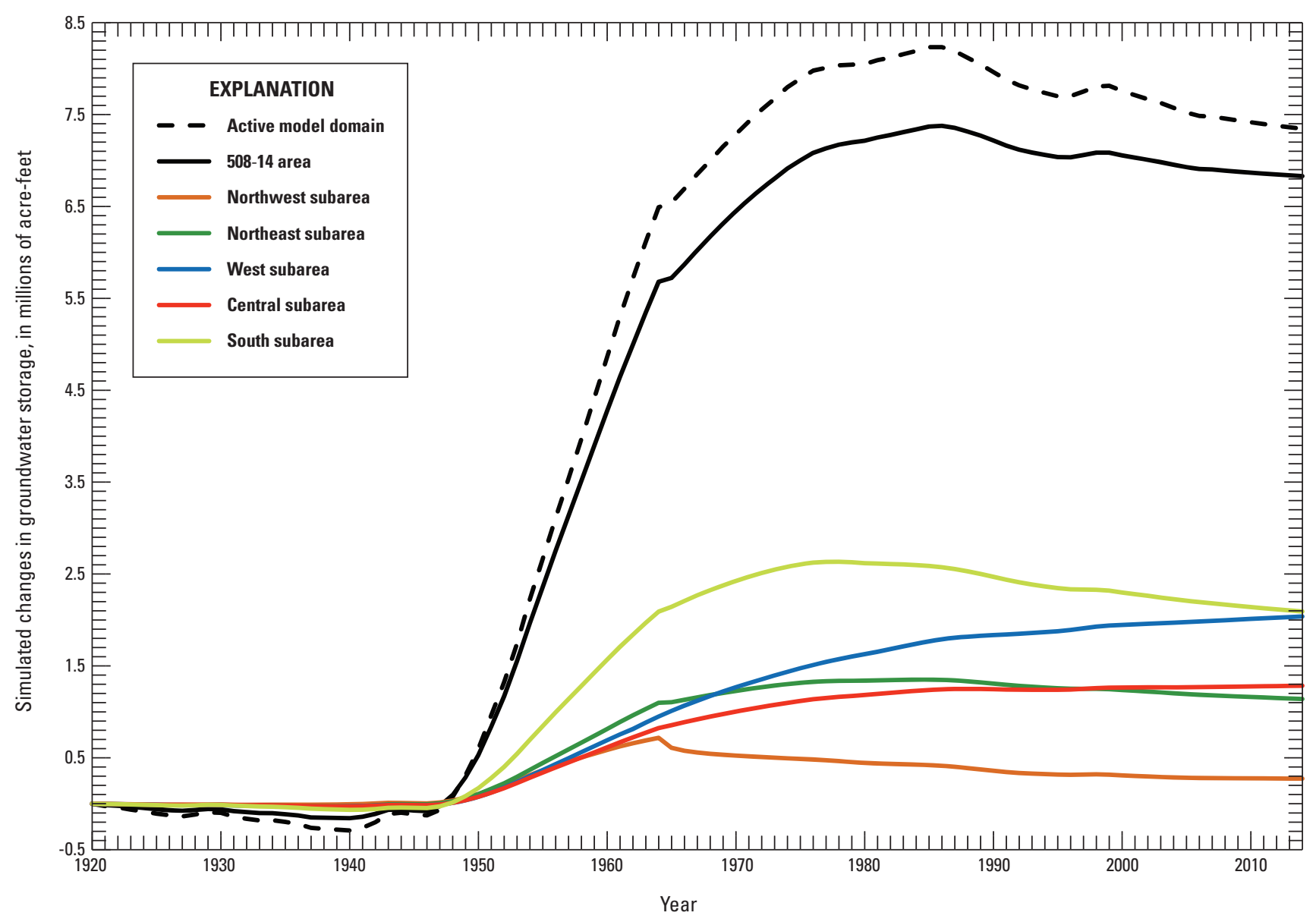

Figure 17. Simulated changes in groundwater storage in the model domain and areas in the 508-14 area, eastern Pasco Basin, Washington,1920-2013. 


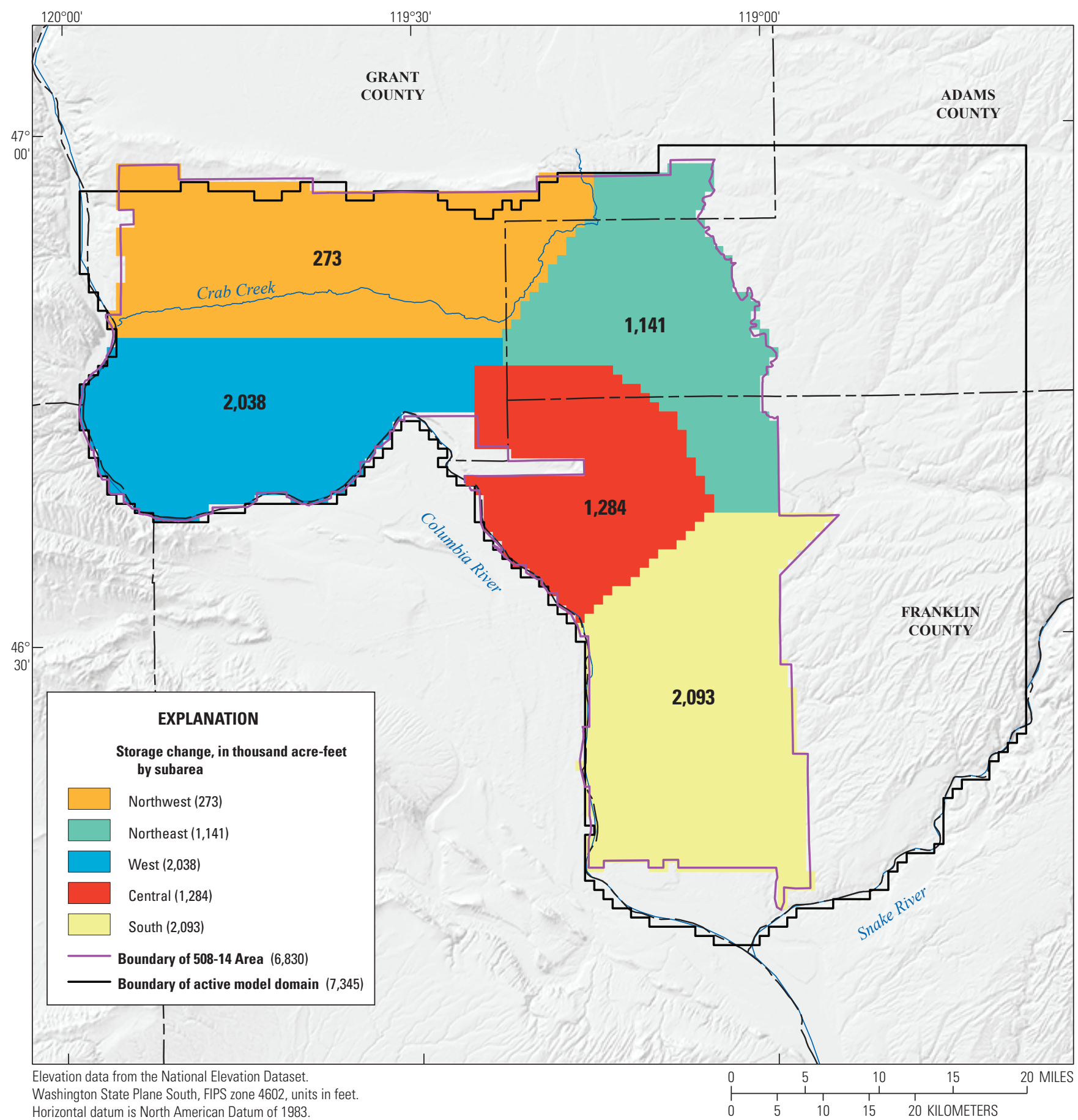

Figure 18. Subareas with summarized simulated change in groundwater storage in the active model domain and 508-14 area, eastern Pasco Basin, Washington. 


\section{Limitations and Appropriate Use of the Model}

The hydrogeologic framework developed for this study is based on available geologic mapping, well drillers' descriptions of material encountered during drilling, and limited site visits to exposed material along bluffs. Correlation of units at depth required interpolating and extrapolating the available data through areas with sparse or no data. The hydrogeologic framework developed for this study is regional in nature, and local conditions may vary.

The absence of historical withdrawal data from wells results in the greatest limitation of the groundwater model. Although the best available land- and water-use data were used, the method that specified the spatial distribution of withdrawals both areally and by aquifer (that is, assigned model layer) is uncertain and introduces error in the headdependent flow boundaries that simulated withdrawal wells because the actual historical withdrawals are unknown. The measured water levels used for model calibration respond to actual groundwater withdrawals, but because the location and magnitude of withdrawals specified in the model is at best an approximation of the actual withdrawals, water levels simulated at observation-well locations cannot reproduce measured water levels with high fidelity. Although the model may not simulate water levels measured at a particular location with high accuracy, simulated changes in water levels, such as those resulting from increased recharge over many years, should be more reliable. Changes in water levels resulting from an additional simulated stress also may be simulated more accurately than the water-level altitudes.

Because groundwater flux and hydraulic conductivity are correlated, and because uncertain groundwater-withdrawal fluxes were specified, relatively homogeneous hydraulicconductivity distributions were simulated to avoid overfitting the water-level measurements during model calibration. The values of hydraulic properties in the model, such as hydraulic conductivity, specific storage, and specific yield, represent large-scale, or "average," values for each simulated hydrogeologic unit. Because each of these units is heterogeneous, values of these properties determined by analysis of aquifer-pumping or slug tests may differ from the model-simulated values.
The simulated values of specific yield were calibrated to measured changes in rising water levels that occurred from about 1952 through the mid-1990s as water filled effective pore space in overburden sediments. Fluid retention as pore space drains can cause a hysteretic effect, resulting in a smaller specific yield during a sediment dewatering phase than during sediment wetting (Maqsoud and others, 2004). Because the possible specific retention of overburden sediments was not modeled, actual water-level declines resulting from a particular groundwater withdrawal may be slightly greater than that simulated with the model. Because specific retention is probably less than about 1 percent, however, this effect would be difficult to discern from effects due to other model uncertainties.

\section{Scenarios}

Four simulations were constructed to quantify the groundwater-level drawdown under hypothetical pumping scenarios. Each scenario simulates a constant withdrawal rate from groundwater withdrawal wells for a 7-year period from early 2014 through 2020. Scenario 1 investigates using a well field to reduce the high water levels thought to contribute to landslides along the White Bluffs area along the Columbia River (fig. 1). The remaining three scenarios use the model to simulate the drawdown that might be caused by permitting an additional groundwater-withdrawal application at two locations where (1) a thick sequence of the Pasco gravels is present about 5 mi northwest of Pasco and (2) the upper and middle Ringold Formations overly the Saddle Mountains Basalt about 13 mi northwest of Pasco. Two scenarios are simulated at the second location - one in which the well is screened only in the upper Ringold Formation, and a second in which the well is screened throughout the Ringold Formation and into the underlying Saddle Mountains Basalt. Each of these three permit-application scenarios simulate an additional $1 \mathrm{Mgal} / \mathrm{d}$ withdrawal from a single cell, which could be provided by one or more wells in that cell. One Mgal/d is typical of the annualized withdrawal rate of currently pending permit applications (John J. Covert, Washington State Department of Ecology, written commun., July 31, 2015). 


\section{Scenario 1-Landslide Abatement}

A field of seven hypothetical groundwater withdrawal wells screened in the upper Ringold Formation (model layer 2) each withdraw 285,714 gal/d, for a total of $2 \mathrm{Mgal} / \mathrm{d}$ $\left(267,361 \mathrm{ft}^{3} / \mathrm{d}\right)$. Four simulated withdrawal wells are positioned $3,281 \mathrm{ft}(1,000 \mathrm{~m})$ apart along a north-south trending line and three wells are positioned 4,640 ft (1,414 m) apart along a northwest to southeast trending line (fig. 19). The simulated well positions generally are between 300 and $3,000 \mathrm{ft}$ northeast of the edge of the upper escarpment of the White Bluffs. Withdrawals were equally distributed among the seven wells for 7 years.

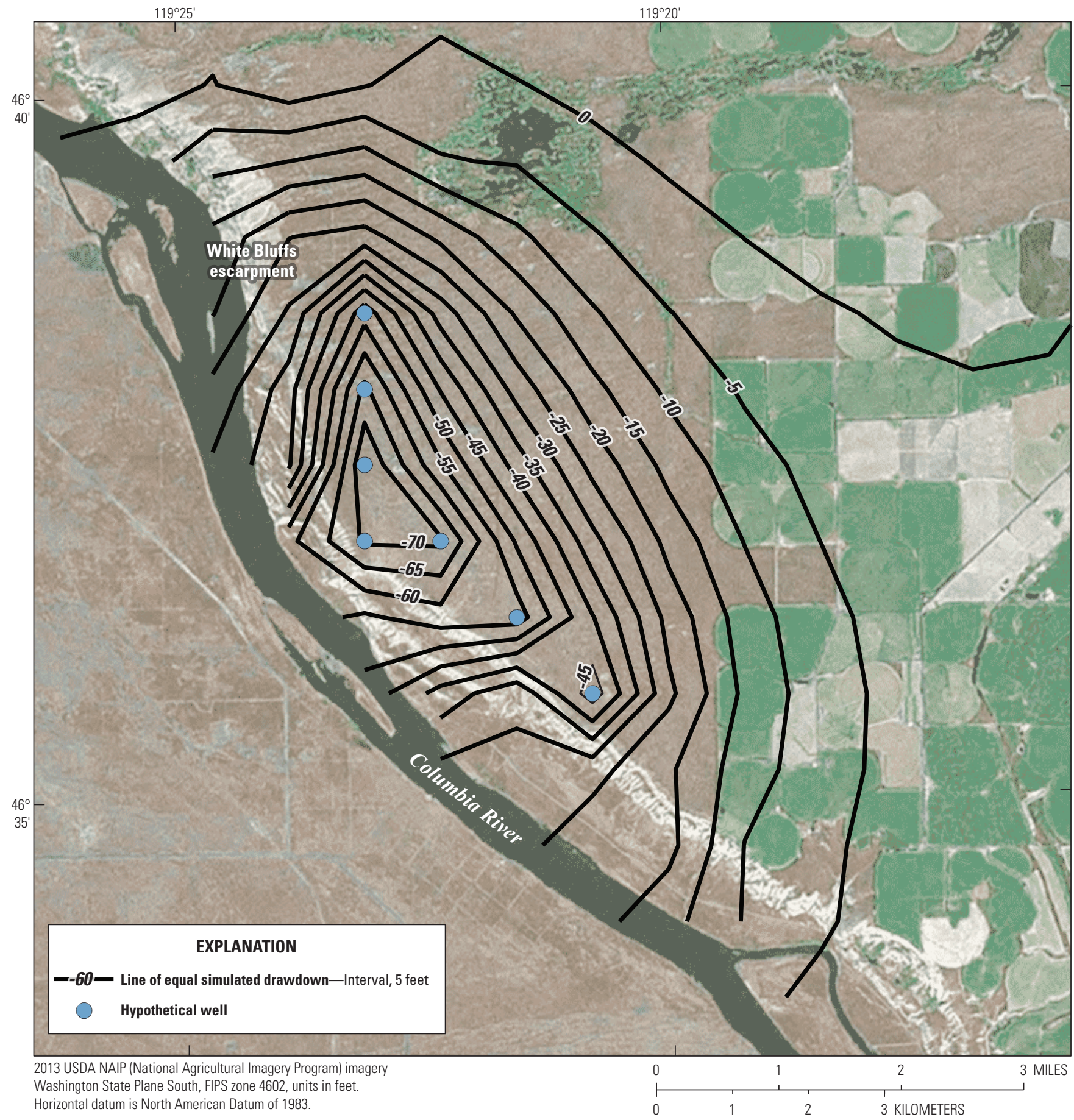

Figure 19. Locations of hypothetical wells and simulated drawdown after 7 years of withdrawals at 2 million gallons per day near White Bluffs, eastern Pasco Basin, Washington. 
Drawdowns after 7 years along the edge of the White Bluffs escarpment, where the cliffs can be unstable and prone to landslides (fig. 19), range from 30 to $70 \mathrm{ft}$ within a distance of about $3,000 \mathrm{ft}$ from a well. The simulated hydrograph for a hypothetical observation well located near the central pumping well (fig. 20) indicates the water-level rise resulting from irrigation since 1947, and $78 \mathrm{ft}$ of drawdown resulting from the hypothetical well field withdrawals that begin in 2014. Drawdown of about $60 \mathrm{ft}$, or 76 percent of the 7-year drawdown, occurs after 4 years. Although the model simulates the drawdown resulting from the specified withdrawals, low hydraulic conductivity of the upper Ringold Formation sediments may limit the withdrawal rates achievable from actual wells.

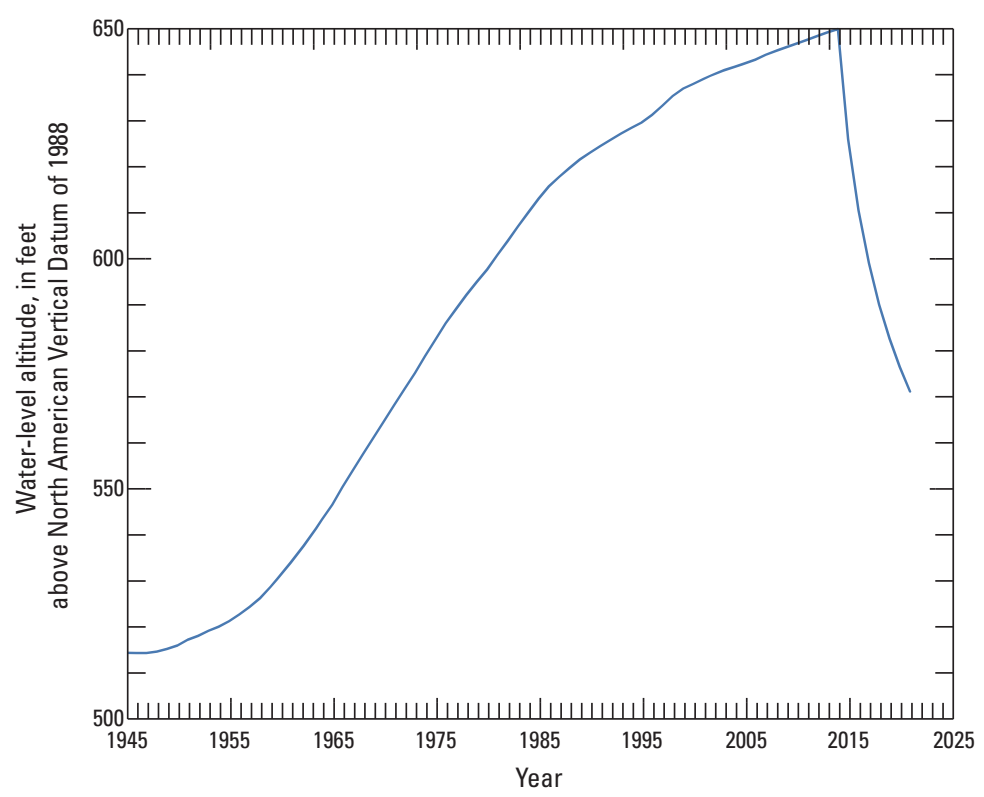

Figure 20. Simulated water-level altitudes in the upper Ringold Formation near the middle of the hypothetical well field near White Bluffs, eastern Pasco Basin, Washington.

\section{Scenario 2-Withdrawal from Pasco Gravels}

The relatively small drawdown that might result from an additional withdrawal from the Pasco gravels, which have high hydraulic conductivity, was simulated with a 7 -year withdrawal at $1 \mathrm{Mgal} / \mathrm{d}$ about $5 \mathrm{mi}$ northwest of Pasco, Washington (location A in fig. 21), where the Pasco gravels are about $200 \mathrm{ft}$ thick.

The screen of the hypothetical well at this location is in the Pasco gravels, which supply all of the specified withdrawal. The hydrograph of simulated water-level altitudes for the model cell of the additional simulated withdrawal depicts a water-level rise of about $63 \mathrm{ft}$ from 1948 to 1976, followed by a water-level decline of about $1 \mathrm{ft} / \mathrm{yr}$ from 1976 to 2014 because of decreased recharge and regional groundwater withdrawals (fig. 22). When the additional withdrawal is simulated in 2015, the rate of water-level decline accelerates, declining $3 \mathrm{ft}$ in the year of well activation, but resumes the previous rate of about $1 \mathrm{ft} / \mathrm{yr}$ in subsequent years. The additional water-level decline created by this withdrawal from the Pasco gravels is barely discernible. 


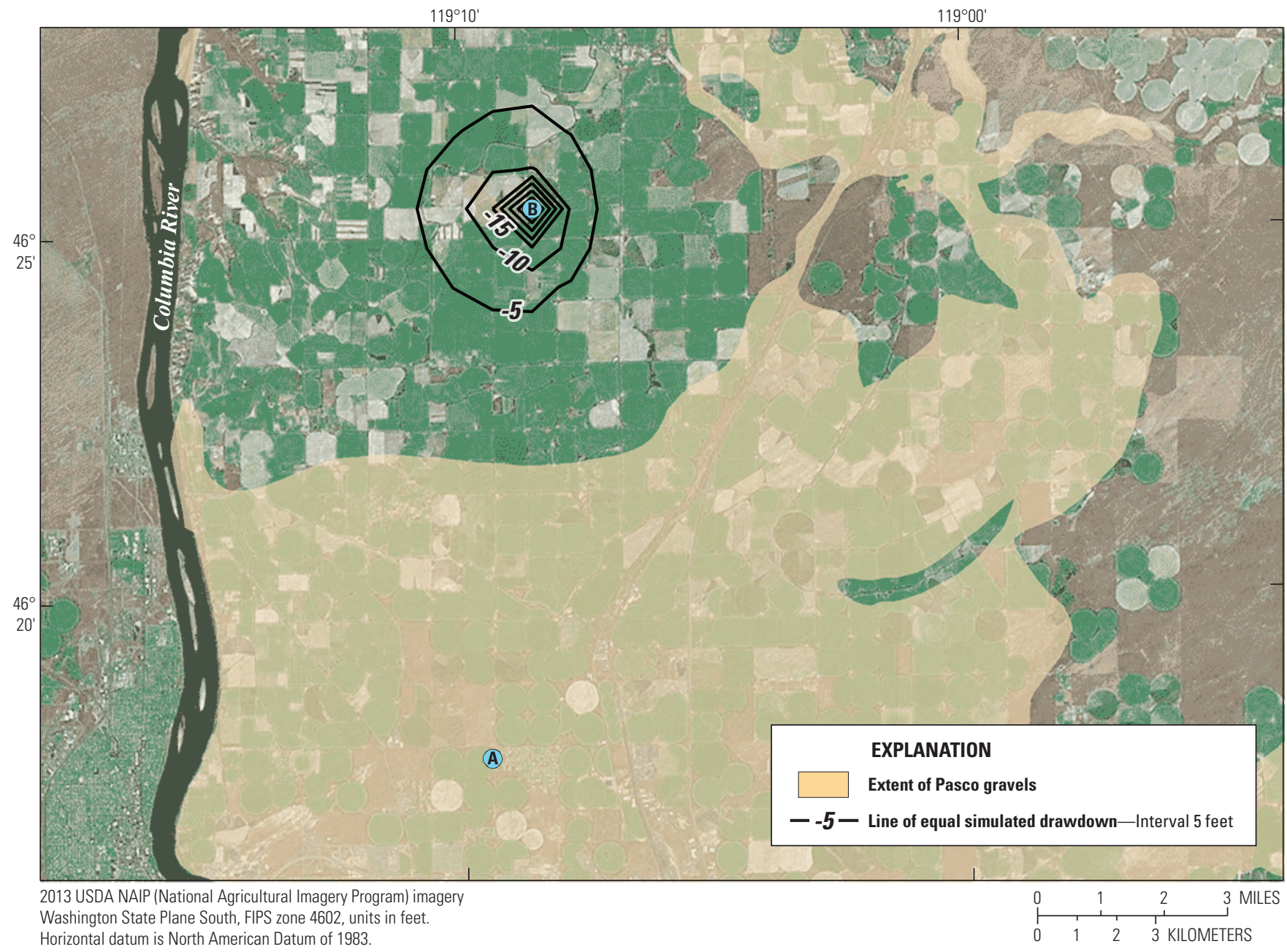

Figure 21. Extent of the Pasco gravels, locations of wells screened in the Pasco gravels (location A) and upper Ringold Formation (location B), and the simulated drawdown after 7 years of an additional 1 million gallons per day withdrawal from the upper Ringold Formation, eastern Pasco Basin, Washington.

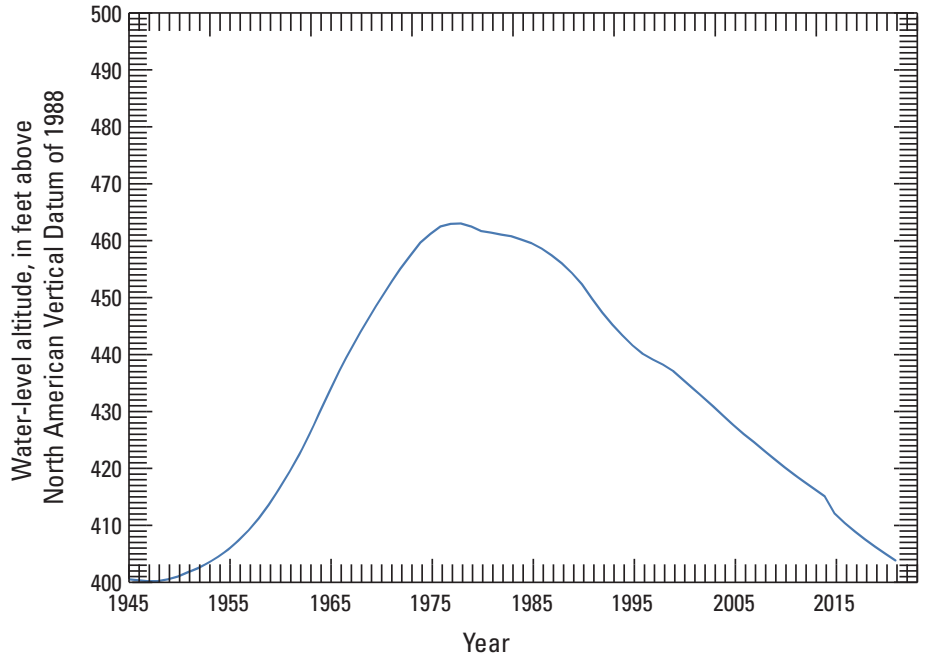

Figure 22. Simulated water-level altitudes where an additional 1 million gallon per day withdrawal was specified from a well screened in the Pasco gravels, eastern Pasco Basin, Washington. Well at location A in figure 21. 


\section{Scenario 3-Withdrawal from Upper Ringold Formation}

In contrast to scenario 2, the drawdown that may result in overburden sediments where the high-conductivity Pasco gravels are not present was simulated by specifying an additional $1 \mathrm{Mgal} / \mathrm{d}$ withdrawal from the upper Ringold Formation 13 mi north-northwest of Pasco (location $B$ in fig. 21). The simulated thicknesses of the upper Ringold Formation, middle Ringold Formation, and Saddle Mountains
Basalt units at this location are 315, 118, and $300 \mathrm{ft}$, respectively. The hydrograph of simulated water-level altitudes where this withdrawal is imposed depicts about $38 \mathrm{ft}$ of drawdown at the top and in the middle of the upper Ringold Formation, but negligible drawdown in the underlying middle Ringold Formation and Saddle Mountains Basalts units (fig. 23). The 7-year drawdown caused by this simulated withdrawal decreases to $5 \mathrm{ft}$ at a distance of $1-13 / 4$ mi from the withdrawal well (fig. 21).

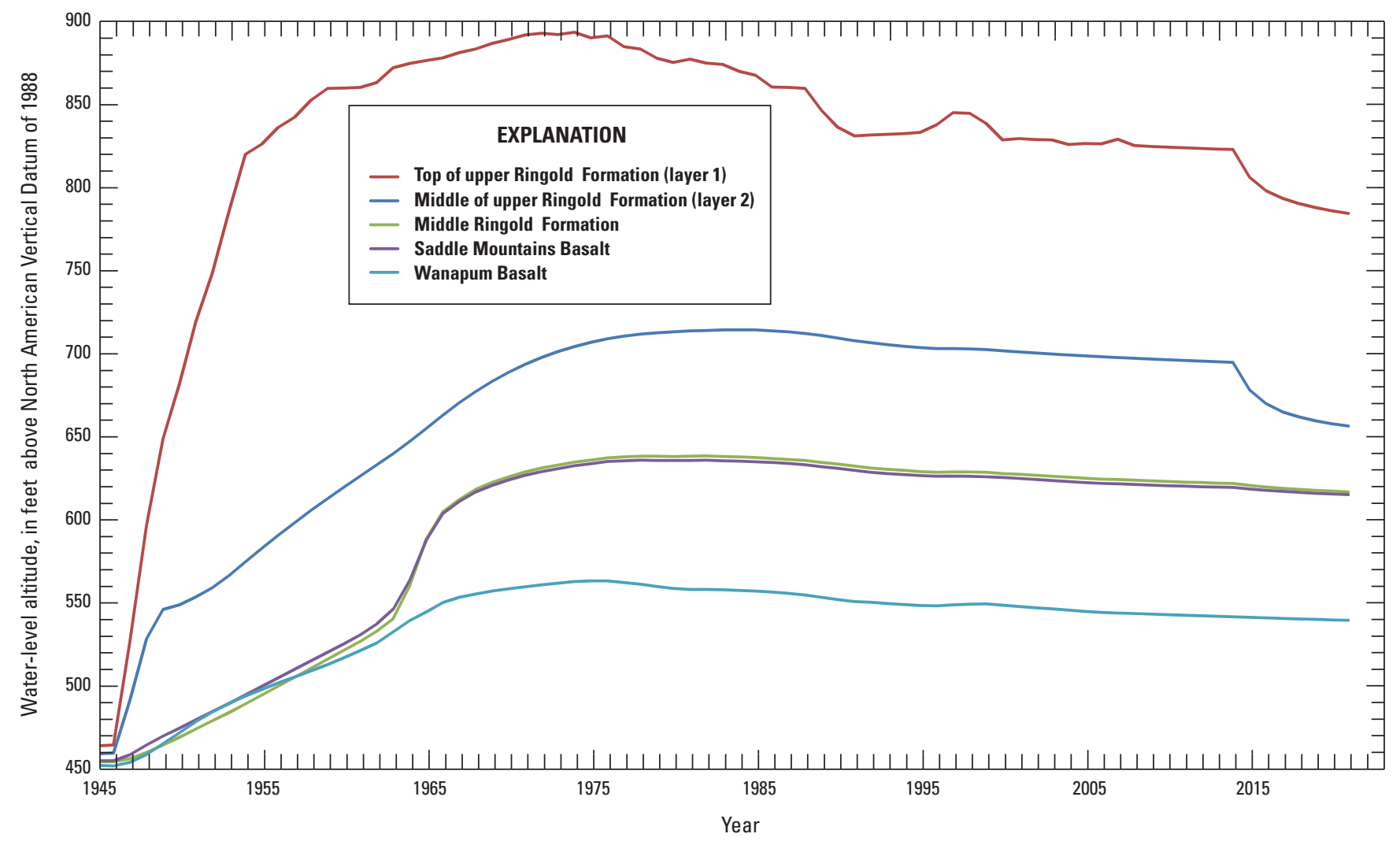

Figure 23. Simulated water-level altitudes for the upper and middle Ringold Formations, and the Saddle Mountains and Wanapum Basalts where an additional 1 million gallon per day withdrawal was specified from a well screened in the upper Ringold Formation, eastern Pasco Basin, Washington. Well at location B in figure 21. 


\section{Scenario 4-Withdrawal from Ringold Formation and Saddle Mountains and Wanapum Basalts}

A more likely scenario than scenario 3 where Pasco gravels are not present is for an additional withdrawal well to be screened through the Ringold Formation and into the underlying basalt formation. This was simulated by specifying an additional $1 \mathrm{Mgal} / \mathrm{d}$ withdrawal from a well screened in the upper and middle Ringold Formations and the Saddle Mountains Basalt at the same location as in scenario 3 (location B in fig. 21). In this scenario, the simulated 7-year drawdown at the top and in the middle of the upper Ringold Formation is $26 \mathrm{ft}$, or about $12 \mathrm{ft}$ less than in scenario 3 (fig. 24). About $12 \mathrm{ft}$ of drawdown also occur in the middle Ringold Formation and Saddle Mountains Basalt because the withdrawal well also is screened in those formations in this scenario. Simulated flows from the upper and middle Ringold Formations and Saddle Mountains Basalt provide about 64,21 , and 15 percent of the $1 \mathrm{Mgal} / \mathrm{d}$ total withdrawal specified from this multi-aquifer well. Despite the lower hydraulic conductivity of the upper Ringold Formation, its large thickness at this location results in the relatively large proportion of water withdrawn from the hypothetical production well. The simulated hydrographs (fig. 24) indicate the downward vertical hydraulic gradient at the location of the hypothetical well.

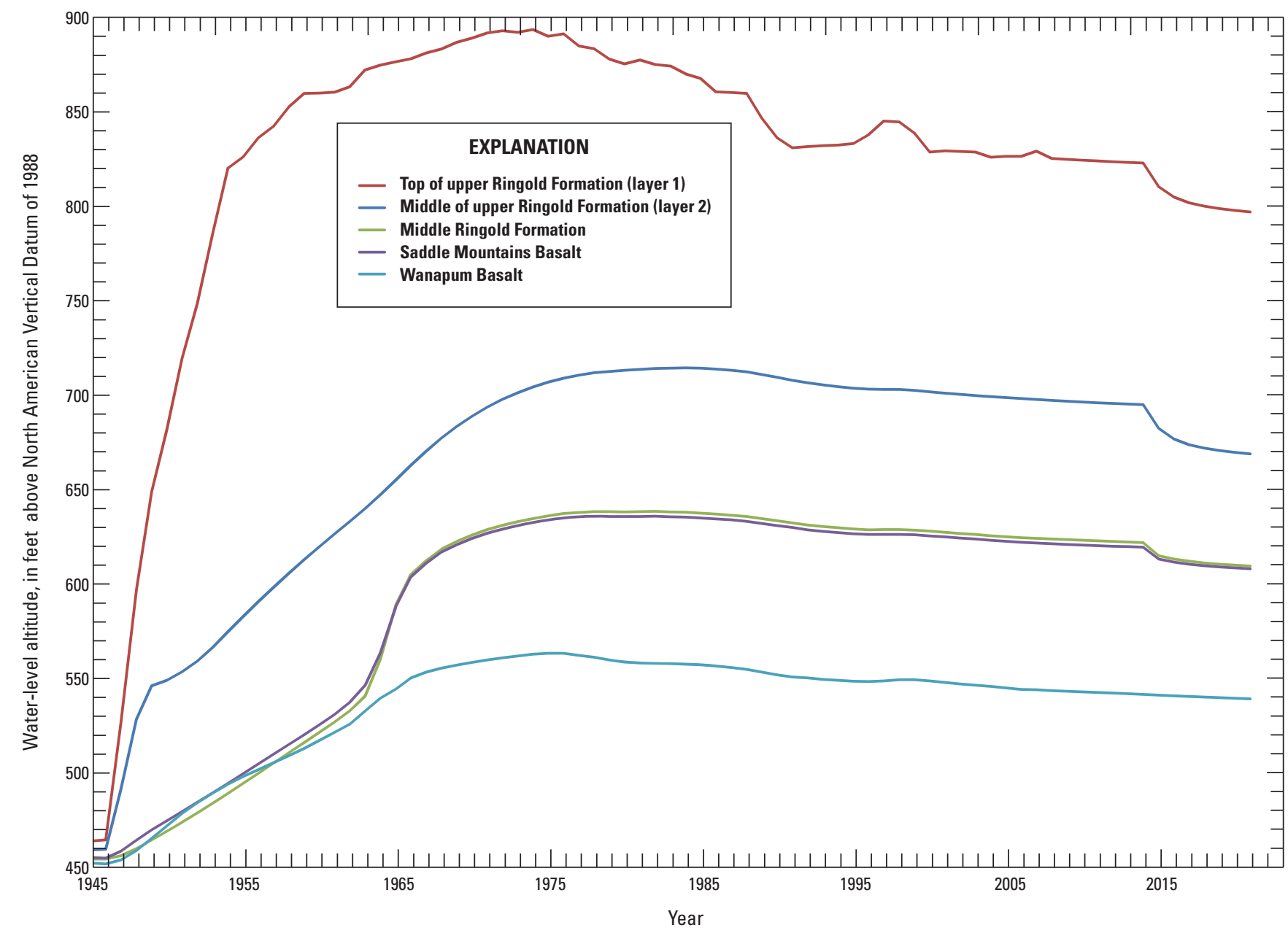

Figure 24. Simulated water-level altitudes for the upper and middle Ringold Formations, and Saddle Mountains and Wanapum Basalts where an additional 1 million gallon per day withdrawal was specified from a well screened through the upper and middle Ringold Formation and Saddle Mountains Basalt, eastern Pasco Basin, Washington. Well at location B in figure 21. 


\section{Summary}

The Miocene Columbia River Basalt Group and younger sedimentary deposits of lacustrine, fluvial, eolian, and cataclysmic-flood origin compose the aquifer system of the eastern Pasco Basin in Washington. Irrigation return flow and canal leakage from the Columbia Basin Project have recharged this aquifer system under parts of the eastern Pasco Basin since 1952. Groundwater levels in the sedimentary overburden have risen substantially in some areas of the eastern Pasco Basin, and may contribute to landslides along the Columbia River and septic system failures, among other problems. State and local water-resource managers are considering extracting the additional stored groundwater to supply increasing demand, as well as possibly mitigating problems caused by the increased water levels. The objectives of this study were to (1) define the area hydrogeology, (2) determine rates and directions of groundwater flow through the aquifer system, (3) quantify the effect of anthropogenic recharge and groundwater withdrawals on groundwater storage, and (4) simulate the effects of groundwater-management scenarios.

To address the objectives of this study, the U.S.

Geological Survey developed a transient groundwater model of the eastern Pasco Basin that quantifies changes in groundwater flow and storage. The model uses a 1-kilometer finite difference grid with MODFLOW-NWT, and is constrained by logs and water levels from 846 wells in the study area. Eight model layers represent five overburden hydrogeologic units and underlying basalt formations. Head-dependent flux boundaries represent the Columbia and Snake Rivers to the west and south, respectively, discharge through groundwater withdrawal wells, underflow to and (or) from adjacent areas to the northeast, and discharge to agricultural drains and springs. Specified flux boundaries represent recharge from precipitation and anthropogenic sources, including irrigation return flow and leakage from water-distribution canals. The model was calibrated with the parameter-estimation code PEST++ to groundwater levels observed from 1907 through 2013 and discharge to springs and agricultural drains observed or estimated from 1986 to 1987. A simulated increase of 6.8 million acre-feet in groundwater storage in the 508-14 administrative area since pre-development results from anthropogenic sources of recharge into the aquifer system. Four hypothetical groundwater-withdrawal simulations estimate the water-level drawdowns that might result from various pumping scenarios. Scenario 1 simulates a 2 million gallon per day (Mgal/d) groundwater withdrawal from a field of seven wells screened in the upper Ringold Formation on the White Bluffs along the Columbia River. Simulated drawdowns ranging from 30 to 70 feet along the White Bluffs near the well field after 7 years may reduce the susceptibility of this area to landslides. Scenarios 2-4 simulate the drawdowns resulting from an additional groundwater withdrawal of $1 \mathrm{Mgal} / \mathrm{d}$ in wells screened in either the Pasco gravels, the upper Ringold Formation, or both the Ringold Formation and underlying basalt. Whereas withdrawals from the Pasco gravels generate negligible drawdown, withdrawals from the Ringold Formation generate more significant drawdown, although the water produced from wells screened only in sediments with low hydraulic conductivity may be limited.

\section{Acknowledgments}

The authors would like to thank the many people who have contributed to our understanding of the hydrogeology of the Pasco Basin, and the personnel of the Bureau of Reclamation and Washington State Department of Ecology involved in the 508-14 Area Groundwater Management Program. U.S. Geological Survey colleagues Devin Galloway, Andrew Long, and Michelle Sneed provided thoughtful and helpful reviews of the draft manuscript.

\section{References Cited}

Bauer, H.H., and Hansen, A.J., 2000, Hydrology of the Columbia Plateau aquifer system, Washington, Oregon, and Idaho: U.S. Geological Survey Water-Resources Investigations Report 96-4106, $61 \mathrm{p}$.

Bauer, H.H., and Vaccaro, J.J., 1990, Estimates of ground-water recharge to the Columbia Plateau Regional Aquifer System, Washington, Oregon, and Idaho, for predevelopment and current land-use conditions: U.S. Geological Survey WaterResources Investigations Report 88-4108, 37 p., 2 pls.

Bergeron, M.P., Freshly, M.D., Last, G.V., and Mitchell, P.J., 1986, Development of the Hanford three-dimensional groundwater flow model: Richland, Wash., Battelle Pacific Northwest Laboratory, $14 \mathrm{p}$.

Bierschenk, W.H., 1957, Hydraulic characteristics of Hanford aquifers: Richland, Wash., General Electric, Hanford Atomic Products Operation, AEC Research and Development Report, Radioactive Wastes, HW-48916, 38 p.

Bolke, E.L., and Skrivan, J.A., 1981, Digital-model simulation of the Toppenish alluvial aquifer, Yakima Indian Reservation, Washington: U.S. Geological Survey Open-File Report $81-425,34 \mathrm{p}$.

Brown, R.E., and Brown, D.J., 1965, Problems associated with the extension of the stratigraphic units of south-central Washington, Part I-The late basalt flows, Ellensburg and lower Ringold Formations: Battelle-Northwest, 11 p.

Bureau of Reclamation, 1984, Drainage manual: Denver, Colo., U.S. Government Printing Office, 286 p. 
Burns, E.R., Morgan, D.S., Peavler, R.S., and Kahle, S.C., 2011, Three-dimensional model of the geologic framework for the Columbia Plateau Regional Aquifer System, Idaho, Oregon, and Washington: U.S. Geological Survey Scientific Investigations Report 2010-5246, 44 p.

Burns, E.R., Snyder, D.T., Haynes, J.V., and Waibel, M.S., 2012, Groundwater status and trends for the Columbia Plateau Regional Aquifer System, Washington, Oregon, and Idaho: U.S. Geological Survey Scientific Investigations Report 2012-5261, 52 p.

Davies-Smith, Ann, Bolke, E.L., and Collins, C.A., 1989, Geohydrology and digital simulation of the ground-water flow system in the Umatilla Plateau and Horse Heaven Hills area, Oregon and Washington: U.S. Geological Survey WaterResources Investigations Report 87-4268, 72 p.

Drost, B.W., Cox, S.E., and Schurr, K.M., 1997, Changes in ground-water levels and ground-water budgets, from predevelopment to 1986, in parts of the Pasco Basin, Washington: U.S. Geological Survey Water-Resources Investigations Report 96-4086, 172 p.

Drost, B.W., Ebbert, J.C., and Cox, S.E., 1993, Long-term effects of irrigation with imported water on water levels and water quality: U.S. Geological Survey Water-Resources Investigations Report 93-4060, 19 p.

Drost, B.W., Schurr, K.M., and Lum, W.E., II, 1989a, Selected ground-water information for the Pasco Basin and adjacent areas, Washington, 1986-1989: U.S. Geological Survey OpenFile Report 89-228, 91 p.

Drost, B.W., Schurr, K.M., Ruppert, G.P., and Cox, S.E., 1989b, Well data, surface-water discharge, and nitrate concentrations, February 1986-September 1987, in parts of the Pasco Basin, Washington: U.S. Geological Survey Open-File Report 89-38, $83 \mathrm{p}$.

Drost, B.W., and Whiteman, K.J., 1986, Surficial geology, structure, and thickness of selected geohydrologic units in the Columbia Plateau, Washington: U.S. Geological Survey WaterResources Investigations Report 84-4326, 12 sheets.

Drost, B.W., Whiteman, K.J., and Gonthier, J.B., 1990, Geologic framework of the Columbia Plateau Aquifer System, Washington, Oregon, and Idaho: U.S. Geological Survey Water-Resources Investigations Report 87-4238, 13 p., 10 sheets.

Ebbert, J.C., Cox, S.E., Drost, B.W., and Schurr, K.M., 1996, Distribution and sources of nitrate, presence of fluoride and pesticides, in parts of the Pasco Basin, Washington, 1986-88: U.S. Geological Survey Water-Resources Investigations Report 93-4197, 95 p., 3 pls.

Ely, D.M., Burns, E.R., Morgan, D.S., and Vaccaro, J.J., 2014, Numerical simulation of groundwater flow in the Columbia Plateau Regional Aquifer System, Idaho, Oregon, and Washington (ver. 1.1, January 2015): U.S. Geological Survey Scientific Investigations Report 2014-5127, 90 p., http:// dx.doi.org/10.3133/sir20145127.
Graham, M.J., 1981, Hydrology of the separations area: Richland, Wash., Rockwell International, Rockwell Hanford Operations, RHO-ST-42, 104 p.

Grant County Assessor, 2013, Grant County real property search: Grant County, Washington, database, accessed November 2013, at http://grantwa.taxsifter.com/Search/Results.aspx.

Hansen, A.J., Jr., Vaccaro, J.J., and Bauer, H.H., 1994, Groundwater flow simulation of the Columbia Plateau Regional Aquifer System, Washington, Oregon, and Idaho: U.S. Geological Survey Water-Resources Investigations Report 91-4187, 81 p.

Hill, M.C., and Tiedeman, C.R., 2007, Effective groundwater model calibration - With analysis of data, sensitivities, predictions, and uncertainty: Hoboken, N.J., Wiley, 455 p.

Hsieh, P.A., and Freckleton, J.R., 1993, Documentation of a computer program to simulate horizontal-flow barriers using the U.S. Geological Survey's modular three-dimensional finitedifference ground-water flow model: U.S. Geological Survey Open-File Report 92-477, 32 p.

Hutchinson, M.F., 1989, A new method for gridding elevation and streamlining data with automated removal of pits: Journal of Hydrology, v. 106, p. 211-232.

Kahle, S.C., Morgan, D.S., Welch, W.B., Ely, D.M., Hinkle, S.R., Vaccaro, J.J., and Orzol, L.L., 2011, Hydrogeologic framework and hydrologic budget components of the Columbia Plateau Regional Aquifer System, Washington, Oregon, and Idaho: U.S. Geological Survey Scientific Investigations Report 2011-5124, 66 p., http://pubs.usgs.gov/sir/2011/5124/.

Khaleel, R., and Freeman, E.J., 1995, Variability and scaling of hydraulic properties for 200 area soils, Hanford Site: Richland, Wash., Westinghouse Hanford Company, WHC-EP-0883 [variously paged].

Leake, S.A., and Claar, D.V., 1999, Computer programs and procedures for telescopic mesh refinement using MODFLOW: U.S. Geological Survey Open-File Report 99-238, 53 p.

Lidke, D.J., compiler, 2002, Fault number 562a, Saddle Mountains structures, Saddle Mountains Fault: U.S. Geological Survey Quaternary fault and fold database of the United States, accessed May 21, 2015, at http://earthquakes.usgs.gov/hazards/ qfaults.

Lindsey, K.A., 1996, Miocene-Pliocene Ringold Formation and associated deposits of the ancestral Columbia River system, south-central Washington and north-central Oregon: Washington Department of Natural Resources, Division of Geology and Earth Resources Open-File Report 96-8, 45 p.

Lindsey, K., Tolan, T., Nielson, M., and Loper, S., 2007, Geologic framework of the suprabasalt sediment aquifer system, Columbia Basin Ground Water Management area of Adams, Franklin, Grant, and Lincoln Counties, Washington, edition 1: Prepared for Columbia Basin Ground Water Management Area by GSI Water Solutions, Inc. [variously paged]. 
Lum, W.E., II, Smoot, J.L., and Ralston, D.R., 1990, Geohydrology and numerical model analysis of groundwater flow in the Pullman-Moscow area, Washington and Idaho: U.S. Geological Survey Water-Resources Investigations Report 89-4103, 73 p., accessed June 8, 2009, at https://pubs.er.usgs. gov/publication/wri894103.

Maqsoud, A., Bussière, B., Mbonimpa, M., and Aubertin, M., 2004, Hysteresis effects on the water retention curve-A comparison between Laboratory results and predictive models: 57th Canadian Geotechnical Conference and 5th Joint CGS/ IAH-CNC Conference, session 3A, p. 8-15.

Meyers, D.A., Last, G.V., and Freshley, M.D., 1985, Status report on the hydrogeologic conceptual model for the unconfined aquifer at the Hanford Site: Richland, Wash., Battelle Pacific Northwest Laboratories, letter report, $23 \mathrm{p}$.

Newcomb, R.C., Strand, J.R., and Frank, F.J., 1972, Geology and ground-water characteristics of the Hanford Reservation of the U.S. Atomic Energy Commission, Washington: U.S. Geological Survey Professional Paper 717, 78 p., 3 pls., http:// pubs.usgs.gov/pp/0717/report.pdf.

Niswonger, R.G., Panday, Sorab, and Ibaraki, Motomu, 2011, MODFLOW-NWT, A Newton formulation for MODFLOW-2005: U.S. Geological Survey Techniques and Methods, book 6, chap. A37, 44 p.

Prych, E.A., 1983, Numerical simulation of ground-water flow in Lower Satus Creek Basin, Yakima Indian Reservation, Washington: U.S. Geological Survey Water-Resources Investigations Report 82-4065, $78 \mathrm{p}$.

Singleton, M.J., Maher, K., DePaolo, D.J., Conrad, M.E., and Dresel, P.E., 2005, Dissolution rates and vadose zone drainage from strontium isotope measurements of groundwater in the Pasco Basin, WA unconfined aquifer: Journal of Hydrology, v. 321, p. $39-58$.

Snyder, D.T., and Haynes, J.V., 2010, Groundwater conditions during 2009 and changes in groundwater levels from 1984 to 2009, Columbia Plateau Regional Aquifer System, Washington, Oregon, and Idaho: U.S. Geological Survey Scientific Investigations Report 2010-5040, 12 p., http://pubs.usgs.gov/ $\operatorname{sir} / 2010 / 5040 /$.

Tanaka, H.H., Hansen, A.J., Jr., and Skrivan, J.A., 1974, Digital-model study of ground-water hydrology, Columbia Basin Irrigation Project area, Washington: Washington State Department of Ecology Water-Supply Bulletin No. 40, 60 p.

Thorne, P.D., and Newcomer, D.R., 1992, Summary and evaluation of available hydraulic property data for the Hanford Site unconfined aquifer system: Richland, Wash., Pacific Northwest Laboratory, PNL-8337 [variously paged], http:// www.osti.gov/scitech/servlets/purl/10106099.

U.S. Department of Energy, 2002, Standardized stratigraphic nomenclature for post-Ringold-Formation sediments within the Central Pasco Basin: U.S. Department of Energy report DOE/ RL-2002-39, variously paged.
U.S. Geological Survey, 1975, Water resources of the Toppenish Creek basin, Yakima Indian Reservation, Washington: U.S. Geological Survey Water-Resources Investigations Report 74-42, $144 \mathrm{p}$.

Vaccaro, J.J., 1999, Summary of the Columbia Plateau Regional Aquifer-System Analysis, Washington, Oregon, and Idaho: U.S. Geological Survey Professional Paper 1413-A, 51 p., http://pubs.usgs.gov/pp/1413a/report.pdf.

Vaccaro, J.J., Jones, M.A., Ely, D.M., Keys, M.E., Olsen, T.D., Welch, W.B., and Cox, S.E., 2009, Hydrogeologic framework of the Yakima River Basin aquifer system, Washington: U.S. Geological Survey Scientific Investigations Report 2009-5152, 106 p., http://pubs.usgs.gov/sir/2009/5152/.

Vaccaro, J.J., Kahle, S.C., Ely, D.M., Burns, E.R., Snyder, D.T., Haynes, J.V., Olsen, T.D., Welch, W.B., and Morgan, D.S., 2015, Groundwater availability of the Columbia Plateau Regional Aquifer System, Washington, Oregon, and Idaho: U.S. Geological Survey Professional Paper 1817, 87 p., http:// dx.doi.org/10.3133/pp1817.

Vermeul, V.R., Bergeron, M.P., Cole, C.R., Murray, C.J., Nichols, W.E., Scheibe, T.D., Thorne, P.D., Waichler, S.R., and Xie, Y., 2003, Transient inverse calibration of the sitewide groundwater flow model (ACM-2) - FY03 progress report: Richland, Wash., Pacific Northwest National Laboratory, PNNL-14398 [variously paged].

Vermeul, V.R., Cole, C.R., Bergeron, M.P., Thorne, P.D., and Wurstner, S.K., 2001, Transient inverse calibration of sitewide groundwater model to Hanford Operational Impacts from 1943 to 1996-Alternative conceptual model considering interaction with uppermost basalt confined aquifer: Richland, Wash., Pacific Northwest National Laboratory, PNNL-13623 [variously paged].

Washington Division of Geology and Earth Resources, 2005, Digital 1:100,000-scale geology of Washington State, version 1.0: Washington Division of Geology and Earth Resources Open-File Report 2005-3.

Welter, D.E., Doherty, J.E., Hunt, R.J., Muffels, C.T., Tonkin, M.J., and Schreüder, W.A., 2012, Approaches in highly parameterized inversion-PEST++, a Parameter ESTimation code optimized for large environmental models: U.S. Geological Survey Techniques and Methods, book 7, chap. C5, $47 \mathrm{p}$.

Whiteman, K.J., Vaccaro, J.J., Gonthier, J.B., and Bauer, H.H., 1994, The hydrogeologic framework and geochemistry of the Columbia Plateau Aquifer System, Washington, Oregon, and Idaho: U.S. Geological Survey Professional Paper 1413-B, 73 p., accessed February 11, 2008, at http://pubs.usgs.gov/ pp/1413b/report.pdf.

Wurstner, S.K., Thorne, P.D., Chamness, M.A., Freshley, M.D., and Williams, M.D., 1995, Development of a threedimensional groundwater model of the Hanford Site unconfined aquifer system-FY 1995 status report: Richland, Wash., Pacific Northwest Laboratory, PNL-10886 [variously paged]. 
Publishing support provided by the U.S. Geological Survey

Science Publishing Network, Tacoma Publishing Service Center

For more information concerning the research in this report, contact the Director, Washington Water Science Center

U.S. Geological Survey

934 Broadway, Suite 300

Tacoma, Washington 98402

http://wa.water.usgs.gov 

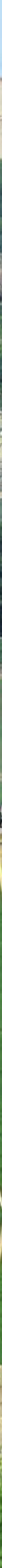